\title{
Journal of Iberian Geology \\ Geological interpretation of two virtual outcrops of deformed Palaeozoic rocks (NW Iberian Peninsula) using 3D Stereo VDT in a computer assisted virtual environment (CAVE TM) \\ --Manuscript Draft--
}

\begin{tabular}{|c|c|c|}
\hline Manuscript Number: & \multicolumn{2}{|l|}{ JIBG-D-19-00004R1 } \\
\hline Article Type: & \multicolumn{2}{|l|}{ Research Paper } \\
\hline \multirow[t]{3}{*}{ Funding Information: } & $\begin{array}{l}\text { Ministerio de Economía y Competitividad } \\
\text { (CGL2015-66997-R) }\end{array}$ & Not applicable \\
\hline & $\begin{array}{l}\text { European Fund for Regional Development } \\
\text { (FEDER) } \\
\text { (CGL2015-66997-R) }\end{array}$ & Not applicable \\
\hline & $\begin{array}{l}\text { Repsol Exploración S.A. } \\
(\mathrm{CN}-16-014)\end{array}$ & Not applicable \\
\hline Abstract: & \multicolumn{2}{|c|}{$\begin{array}{l}\text { An in-house software for Computer Assisted Virtual Environments (CAVE TM), called } \\
\text { 3D Stereo Virtual Drawing Tool (3D Stereo VDT), is presented through the } \\
\text { interpretation of bedding and structural elements in two virtual outcrops. The main } \\
\text { purpose of this software is to perform geological interpretations of point clouds through } \\
\text { a friendly interface. 3D trackers allow the drawing of points and lines. Such elements } \\
\text { may represent all sorts of geological features: bedding, unconformities, fractures, fold } \\
\text { axial surfaces, axes, etc. One of the outcrops is a small, close-range point cloud } \\
\text { constructed using field photographs of a beach cliff, whereas the other is a bigger, } \\
\text { aerial point cloud built with Google Earth images of a valley slope. Both irregular and } \\
\text { partly inaccessible outcrops consist of folded and faulted Palaeozoic rocks in the } \\
\text { northwest portion of the Iberian Peninsula. The 3D analysis of these outcrops allowed } \\
\text { us to supply new orientation data as well as ideas regarding the characteristics, origin } \\
\text { and evolution of the mapped structures in relation to their setting. }\end{array}$} \\
\hline Corresponding Author: & \multicolumn{2}{|l|}{$\begin{array}{l}\text { Hodei Uzkeda, Ph.D. } \\
\text { Universidad de Oviedo } \\
\text { Oviedo, Asturias SPAIN }\end{array}$} \\
\hline First Author: & \multicolumn{2}{|l|}{ Santiago Martín } \\
\hline \multicolumn{3}{|l|}{ First Author Secondary Information: } \\
\hline \multirow[t]{4}{*}{ Order of Authors: } & \multicolumn{2}{|l|}{ Santiago Martín } \\
\hline & \multicolumn{2}{|l|}{ Hodei Uzkeda, Ph.D. } \\
\hline & \multicolumn{2}{|l|}{ Josep Poblet } \\
\hline & \multicolumn{2}{|l|}{ Mayte Bulnes } \\
\hline \multicolumn{3}{|c|}{ Order of Authors Secondary Information: } \\
\hline Author Comments: & \multicolumn{2}{|c|}{$\begin{array}{l}\text { The software itself, as well as complementary material (such as its manual and videos } \\
\text { showing how it works), can be made available by storing it to one of our servers. }\end{array}$} \\
\hline
\end{tabular}




\title{
GEOLOGICAL INTERPRETATION OF TWO VIRTUAL OUTCROPS OF DEFORMED PALAEOZOIC ROCKS (NW IBERIAN PENINSULA) USING 3D STEREO VDT IN A COMPUTER ASSISTED VIRTUAL ENVIRONMENT $\left(\mathrm{CAVE}^{\mathrm{TM}}\right)$
}

\author{
Santiago Martín ${ }^{1}$, Hodei Uzkeda ${ }^{2, *}$, Josep Poblet ${ }^{2}$, Mayte Bulnes ${ }^{2}$ \\ ${ }^{1}$ Departamento de Construcción e Ingeniería de Fabricación, Universidad de Oviedo, Campus de Viesques, Edificio \\ Departamental 6, 33203 Gijón, Spain, EU \\ (E-mail: martinsantiago@uniovi.es) \\ ${ }^{2}$ Departamento de Geología, Universidad de Oviedo, C/Jesús Arias de Velasco s/n, 33005 Oviedo, Spain, EU \\ (E-mail: hodei@geol.uniovi.es, +34985103120; jpoblet@geol.uniovi.es; maite@geol.uniovi.es) \\ * Corresponding author
}

\section{Abstract}

An in-house software for Computer Assisted Virtual Environments (CAVE $\left.{ }^{T M}\right)$, called 3D Stereo Virtual Drawing Tool (3D Stereo VDT), is presented through the interpretation of bedding and structural elements in two virtual outcrops. The main purpose of this software is to perform geological interpretations of point clouds through a friendly interface. 3D trackers allow the drawing of points and lines. Such elements may represent all sorts of geological features: bedding, unconformities, fractures, fold axial surfaces, axes, etc. One of the outcrops is a small, close-range point cloud constructed using field photographs of a beach cliff, whereas the other is a bigger, aerial point cloud built with Google Earth images of a valley slope. Both irregular and partly inaccessible outcrops consist of folded and faulted Palaeozoic rocks in the northwest portion of the Iberian Peninsula. The 3D analysis of these outcrops allowed us to supply new orientation data as well as ideas regarding the characteristics, origin and evolution of the mapped structures in relation to their setting.

Keywords: 3D geological dataset, aerial point cloud, close-range point cloud, Computer Assisted Virtual Environment $\left(\mathrm{CAVE}^{\mathrm{TM}}\right)$, geological interpretation, virtual outcrop

\section{Introduction}

The technological advances developed in recent times have made easier to obtain 3D data in the field of Earth Sciences. This has occurred both in the case of subsurface geology, with the introduction of 3D seismic volumes (Biondi 2006 and references therein), and in the case of surface geology, with various techniques such as stereoscopic visualization/interpretation of outcrop, aerial or satellite photographs using specific software (e.g., Berger et al. 1992; Dueholm et al. 1993; Martín et al. 2013), obtaining data in the field using laser rangefinders or total stations (e.g., Xu et al. 2001; Uzkeda et al. 2010), remote mapping from orthophotographs and geological maps draped over digital elevation models managed using Geographical Information Systems (GIS) (e.g., Banerjee and Mitra 2004; Dhont et al. 2005), and visualization/interpretation of virtual outcrops (e.g., Xu et al. 2000; Buckley et al. 2008; Hodgetts 2013) amongst others. Nowadays, one of the most common methods employed to acquire 3D geological datasets from rock outcrops is the creation of photorealistic virtual outcrops in the form of georeferenced point clouds or textured triangular meshes. The two most used strategies to generate these 3D digital models of outcrops are: Light Detection and Ranging (LIDAR) / terrestrial laser scanner (TLS) (Pringle et al. 2004; Bellian et al. 2005; Trinks et al. 2005; McCaffrey et al. 2010), and photogrammetry (Bemis et al. 2014; Svennevig et al. 2015; Corradetti 2017; Sørensen and Dueholm 2018; Sørensen and Guarnieri 2018) along with the use of Global Positioning Systems (GPS) (Xu et al. 2000; Olariu et al. 2011; Minisini et al. 2014). However, extracting meaningful geological elements from virtual outcrops is still a challenging task. The extraction of fractures from 3D digital outcrops has been the focus of a lot of research. The main reason would be the wide range of applications fracture datasets have (e.g., structural geology, hydrogeology, petroleum geology, engineering geology). Also, because fractures are, in some cases, relatively easy to recognize from photorealistic images of outcrops and their geometry is relatively "predictable" to a certain extent. Semi-automatic and automatic methods have been developed in recent years to identify such fractures and related elements (e.g., Micklethwaite et al. 2012; Vasuki et al. 2014; Casini et al. 2016; Wang et al. 2017). On the contrary, interpretation of other geological elements (bedding, faults, folds, etc.) in a more classical sense from virtual outcrops has received less attention (e.g., Trinks et al. 2005; Minisini et al. 2014; Tavani et al., 2014; Pavlis and Mason 2017). One of the reasons why this type of interpretation is not so developed is that, for instance, bedding may be extremely 
difficult to identify in some photorealistic virtual outcrops, and in addition, its geometry may be almost unpredictable.

Taking into account the issues above, an in-house software, called 3D Stereo Virtual Drawing Tool (3D Stereo VDT), specifically designed to visualize and carry out geological interpretations of virtual outcrops in the form of point clouds is presented here. This software runs in a commercial Computer Assisted Virtual Environment (CAVE), which offers a more immersive and intuitive manner to carry out the interpretation than other methods.

To demonstrate the full potential of the 3D Stereo VDT software, the geological interpretation of two outcrops of Devonian and Carboniferous sedimentary rocks from the Cantabrian Zone, a foreland fold-and-thrust belt in the NW Iberian Peninsula have been carried out. These rocks were intensely folded and faulted during the Variscan orogeny of Carboniferous age, and therefore, bedding does not consist of simple planes but of complex geometric surfaces. Furthermore, the sources from which the two point clouds were obtained are different: the point cloud of the first outcrop (Andrín beach) came from photographs taken with a conventional camera in the field, whereas the point cloud of the second outcrop (Cacabillo) was constructed using images extracted from Google Earth. The interpretation of these outcrops, together with the measurement of some geological elements, allowed us to suggest some new considerations about the geology of these areas.

\section{Rationale for using a CAVE and 3D Stereo VDT}

\subsection{D visualization: depth cues}

One of the main issues a geologist faces when attempting to analyse a geological outcrop through a point cloud is the lack of depth cues, which is a key factor for the easy interpretation of 2D images (Swanston and Wade 2001). When a point cloud is shown on the screen, there is not almost any depth cue. Therefore, the geologist has to make a large effort to imagine the actual 3D representation of what is depicted on the computer screen. There are two types of cues to perceive depth: monocular, which only need one observer eye; and binocular (convergences and parallax or retinal disparity), which require both eyes. The resultant depth seen is a compromise between all of them.

\subsubsection{Monocular cues}

As a rule, the monocular cues found in a flat image are considered psychological rather than physiological. The only physiological cue is accommodation, i.e. the increase in optical power by an eye to remain focused on an object, which is not applicable to such images. Some of the most common psychological monocular cues in flat images are:

1) Overlapping or interposition: the retinal image of one object partially obscures that of another making it to appear closer to the observer.

2) Lighting and shading: colours change depending on their angle and distance from lights generating a photorealistic effect.

3) Texture density: the greater the distance to the observer, the greater the density in the retinal pattern.

4) Perspective or conical projection: size and separation of objects decrease as the distance increases. This is one of the most important monocular cues (Durand et al. 2003).

Unfortunately, none of these monocular cues is present in a point cloud, so depth perception must be based on other cues.

\subsubsection{Binocular cues}

As previously stated, there are two binocular cues:

1) Convergence: it is a physiological cue, the eyes turn inward more when the observer is looking at a nearby object than when observing distant ones. It is not applicable in a flat image.

2) Parallax: it is a basic cue of the sense of sight biologically linked to the brain. Each eye perceives a slightly different relative position of the objects in the scene, and this difference is interpreted as a measurement of depth. This is known also as retinal disparity or stereopsis (Howard and Rogers 1995; Rogers and Bradshaw 1993). Regrettably, it is not available in most software tools used to deal with point clouds.

Whereas it is necessary to view the world with two eyes in order to detect stereopsis, there is a functionally similar cue to monocular vision based on the movement of the head from side to side called relative motion parallax. It consists of relative motion between the retinal images of objects at different distances, as the observer's head moves laterally. The kinetic depth effect shows that relative motion may also act as a cue to depth even if seen by a stationary observer (Dijkerman et al. 1999). This is the only depth cue available in most software tools used in analysis and visualization of point clouds, and is the primary reason that geologists repeatedly move a point cloud dataset when interpreting the data. As soon as the movement stops, the depth perception disappears.

\subsection{Advantages of a CAVE}

Considering the points above regarding depth cues, the use of a CAVE to visualize a point cloud is more than 
desirable. A CAVE is an immersive virtual reality environment invented at the University of Illinois in 1992 consisting of projectors, screens and mirrors within a room-sized cube. The users wear 3D glasses inside the CAVE to see the 3D graphics generated and sensors track their movements. Computers control both the visual and the audio aspect. In the virtual scene, user has both motion parallax and stereopsis cues available. He can navigate around the point cloud walking within the CAVE (motion parallax), he can move the point cloud (motion parallax again), and he perceives stereoscopically the depth at any moment (retinal disparity). The result is likely as "being there" but with the advantage of being able to move freely around the object, applying any scale to the object (from metres to hundreds of metres), dealing with any feature of interest directly in $3 \mathrm{D}$, and being able to work with it even when being far away from the real feature and without all the logistical and time limitations that arise when working in certain environments. This capability is especially useful when working in areas of relatively complex geology, where, for instance, there are features only visible at a certain scale or from a determined point of view or orientation.

The use of CAVE systems in Geosciences is not new since, at least, oil companies such as ARCO and Norsk Hydro have installed immersive visualization rooms based on the CAVE, although they mainly employ them for seismic data visualisation (http://wiki.aapg.org/3-D_seismic_data:_immersive_visualization).

\subsection{Peculiarities of $3 D$ Stereo VDT}

Software for 3D visualisation and interpretation of geological data, with similar functionalities, or even more than those of 3D Stereo VDT, has been reported in the literature (Table 1). These software packages are aimed to facilitate the work of Earth Science professionals, such as stratigraphers, geomorphologists, structural geologists, engineering geologists, etc., who wish to obtain 3D geological datasets from rock outcrops.

Although they share a few features, some differences may make 3D Stereo VDT more suitable for these scientists; these particularities are listed below.

1) All the previous software runs in personal computers/workstations, whereas 3D Stereo VDT runs in a CAVE, which would result in better immersion, even when compared to those software that use virtual reality headsets.

2) Apart from computer screens, some of the previous software support stereo views using different types of shutter glasses and anaglyphs (Move, Lime, OpenPlot), however, these 3D systems are used only for visualisation. By contrast, 3D Stereo VDT, as well as MOSIS and VRGS that support virtual reality headsets, allow the user to perform geological interpretations directly in 3D on the point clouds by using 3D trackers.

3) Previous available software uses the computer keyboard as an interface to introduce the different commands, whereas 3D Stereo VDT and MOSIS employ specific controllers (Wii and HTC Vive controllers, respectively).

\section{$3 \quad$ Methodology}

\subsection{Software employed}

The software 3D Stereo VDT allows users to perform geological interpretations over virtual outcrops created as point clouds (Gargollo 2014; Moriano et al. in prep). This software was developed in-house by Santiago Martín. It runs in WorldViz Vizard (version 4.0), is written in Python language and it occupies about 95 MB (including examples). The software is to be used in a two-wall CAVE system (Fig. 1a). The screens, one horizontal and the other vertical, have dimensions of $3 \times 2.2 \mathrm{~m}$ and a resolution of $1400 \times 1050$ pixels each one. A single DELL workstation (Intel (C) Xeon (C) CPU $2.60 \mathrm{GHz}, 16 \mathrm{~GB}$ RAM, 64 bits), equipped with a single NVIDIA Quadro 5000, runs two projectors Christie Mirage, S4k and S6k. NuVISION 60Gx shutter glasses were used, as well as an infrared optical head tracker (ARTTRACK DTRACK 2 System, ART Inc.) with four cameras. The shutter glasses with the in-built positioning system works in conjunction with a handheld device (Wii Remote, herein called Wiimote, + Nunchuk) that operates as a controller to allow the geologist to identify and interpret geological features on the point cloud (Fig. 1b). The infrared cameras track the position of the user, to provide a correct view of the point cloud, and that of the drawing tool. This allows digitizing the geological features at their accurate position. The user interface is a $3 \mathrm{D}$ element linked to the handheld device position.

3D Stereo VDT can open two file types: OBJ Point Cloud (Wavefront 3D Object File) and VDT Project (Virtual Drawing Tool). The point clouds, in ASCII format, may have colour and normal information for each point. To convert a ply cloud (Polygon Model File) to OBJ format, the software MeshLab may be used. MeshLab is an open source and portable software used to process and edit large meshes and point clouds that can be downloaded for free from its official website: http://meshlab.sourceforge.net/. A VDT Project file is an internal file type, generated by 3D Stereo VDT, used to save current work and continue editing later. This type of file stores all the lines created, as well as the translation, rotation and scale modifications applied to the point cloud. The drawn elements, which may contain colour information, can be exported to a DXF (Drawing Exchange Format) file in the original cloud's coordinate system (Fig. 2). 

points and polylines, and edit them using a controller whose colour, transparency and size may be changed. The Nunchuk control stick and its trigger buttons $(\mathrm{C}$ and $\mathrm{Z})$ are used primarily to move, rescale and rotate the point cloud. The main tasks performed with the Wiimote (buttons 1, B, -, +, "Home"), whose position is continuously tracked by infrared cameras, are the digitalization of geological elements of interest on the point cloud and controlling the characteristics of the pointer and the features interpreted.

To facilitate geological interpretation, once created, lines can be extended, shortened and their shape changed by adding points at the end of the line or within it, removing selected points, and moving points freely on the 3D space. The whole line can be deleted as well. In addition, the line colours can be changed, by choosing within a palette of available colours, their width can be broadened or thinned, and their length can be measured in cloud's units (centralleft part of Fig. 3). The reason why the colour and widths of the lines can be changed is to use lines of different colours and widths to distinguish different bed boundaries and unconformities, fractures and fault sets, fold axes and axial surfaces, and other types of interesting geological elements. The purpose of measuring lines is, for example, to measure thicknesses of certain layers in a particular area of the outcrop in order to help recognizing them in another part of the outcrop by comparing their thicknesses amongst other features. The measurement of line lengths can also be used from the structural point of view. For instance, it is possible to measure the displacement undergone by the cut-off points of various horizons along a fault, and thus, determine whether the fault displacement remains constant or it is variable. The variation of fault displacement in a certain direction is a diagnostic feature to distinguish different types of fault-related folds in both contractional and extensional settings (e.g., McConnell et al. 1997). Moreover, 3D Stereo VDT allows applying three different types of transformation options to the entire scene for visualization purposes (upper-left part of Fig. 3). The scene may be scaled, translated on the XZ and XY axes and rotated along a horizontal or vertical axis, with the centre of rotation located at the controller's spatial position. As aforementioned, all the operations are executed using the handheld device illustrated in Fig. 1b.

\subsection{Point cloud generation}

The point clouds with associated colour information from the corresponding images (x-y-z red-blue-green [RGB] files), loaded into 3D Stereo VDT, may be created employing the free software VisualSFM (http://ccwu.me/vsfm) (Wu 2013). This software follows the structure from motion system developed by Wu et al. (2011) (see Carrivick et al. 2016 for a compendium of some applications of structure from motion in Earth Sciences), and sorts out both the camera calibration problem (calculations of focal length, projection centre, radial distortion) and the resection (determining the camera positions for each photograph). To carry out these corrections, the software uses the bundle adjustment method (Triggs et al. 2000; Wu et al. 2011), with automatic detection of matching points using the Scale Invariant Feature Transform (SIFT) algorithm. VisualSFM is also able to load the corresponding parameters and set a fixed calibration if the camera had been calibrated before. In order to create the point cloud, sparse reconstruction is run first, so that the bundle adjustment step uses multicore bundle adjustment automatically. Subsequently, it comes the dense reconstruction by using the Patch-based Multi-view Stereo Software (PMVS2) (http://www.di.ens.fr/pmvs/), which is included in the Clustering Views for Multi-view Stereo Software package (CMVS) (https://www.di.ens.fr/cmvs/), developed by Y. Furukawa and J. Ponce. This software groups the images into manageable packages to make a more exhaustive search, instead of working with all of them at the same time which would be much more expensive from the computational point of view. The package image grouping is based on the previous reconstruction using the bundle adjustment. Four choices are possible in order to handle the point clouds including millions of points with the objective of having better computer performance: a) down-sampling the point cloud for large-scale interpretation when not so much detail is needed, b) dividing the point cloud into smaller portions to be analysed independently, c) deleting areas without interest, and d) obtaining a textured triangulated mesh. Since the chosen outcrops were of relatively manageable size, none of these procedures was necessary.

\subsection{Advantages and disadvantages of the proposed method}

The reason for developing this software for a fully immersive virtual environment, i.e. a CAVE, is that it has the same advantages as working with virtual outcrops in standard computers (i.e. obtaining distortion-free 3D data, all of the outcrop can be visualized including those portions hardly accessible in the field, data available at the laboratory to be analysed and shared at any time), and, additionally, it offers two main further advantages.

1) Computer monitors simulate $3 \mathrm{D}$ views based on perspectives and contrasts between light and shadows and different colours. In contrast, 3D geological interpretation of virtual outcrops in a fully-immersive, virtual-reality environment, such as a CAVE, facilitates the interpreter task because it allows the user to work "as being on the outcrop".

2) In addition, virtual outcrop views in computer monitors require the interpreter to move, rotate and scale (i.e. enlarge and reduce) the image, to properly interpret its geological features because views are usually small. In contrast, geological interpretation in a CAVE requires much less operations because of its larger size and because all the commands can be easily executed using the handheld device. Unlike computer keyboards and conventional computer mice, the use of a Wiimote and a Nunchuk is 
more intuitive, facilitates the user's freedom of movement inside the CAVE in order to interpret the point cloud and all the functionalities are concentrated in a few buttons.

Summarizing, a CAVE-based interpretation becomes more intuitive as it allows the user to focus on digitizing and following the meaningful geological elements along the outcrop instead of searching for the best perspective, light orientation, etc. This leads to a substantial time and effort saving. Of course, the main drawback is that a CAVE infrastructure must be available which, in some cases, may be quite difficult because of its costs and room required.

Regarding the use of point clouds, they usually provide sufficient degree of detail for an optimal geological interpretation of many outcrops. However, it is important to note that point clouds represent discrete data and in some cases, such as very subtle texture changes in the rock face, this may become an obstacle for geological interpretation when high level of detail is required. In these situations, visualizations using textured triangular meshes may be more appropriate. Another obstacle derived from the use of point clouds is constructing point clouds from images with poor texture, i.e. homogeneous rock faces. That is not always successful and large gaps of "no data" might occur because the software is unable to match points in the different images.

\section{$4 \quad$ Application to virtual outcrops}

The two selected outcrops (Fig. 4) involve folded and faulted upper Palaeozoic rocks from the foreland fold-andthrust belt of the Variscan Orogen at western Iberia, known as Cantabrian Zone (Lotze 1945; Julivert et al. 1972). In the Cantabrian Zone a Palaeozoic stratigraphic succession from Cambrian to Carboniferous crops out. It is made up of both siliciclastic (shales, sandstones and conglomerates) and carbonate (marls, limestones and dolomites) sedimentary rocks with sporadic volcanic and coal horizons. The Cantabrian Zone evolved mainly under diagenetic conditions and only some particular regions underwent extremely low or low-grade metamorphism. This belt exhibits a thin-skinned structural style, including different types of thrust systems and fault-related folds. Intense deformation and tectonic foliation are lacking, except for specific, generally small areas (Julivert 1971, 1979, 1981, 1983; Savage 1979, 1981; Pérez-Estaún et al. 1988; Pérez-Estaún and Bastida 1990; Alonso et al. 1992, 2009; Aller et al. 2004 amongst others). The Cantabrian Zone has typical orogenic wedge morphology in section that thins toward the foreland (east). In map view, the structures exhibit a curved trend around an approximately E-W axial surface, with the inner core to the east, following an orocline called Asturian Arc (Fig. 4).

The selected outcrops have irregular shapes with inlets and protrusions, as well as vertical, inclined and horizontal outcrop faces. Thus, traditional geological interpretation of field photographs, and geological cross-sections and structural sketches constructed directly in the field would produce distorted geometries of the structures. In addition, both outcrops include inaccessible areas and bedding correlation along them is difficult because layers are intensely folded and faulted. Due to these reasons, the methodology and workflow described above (Figs. 1, 2 and 3) seemed to be the most appropriate strategy to obtain accurate geological data from these two examples.

\subsection{Terrestrial, ground-based or close-range example: the Andrín outcrop}

The first example consists of an approximately $40 \mathrm{~m}$ width, $30 \mathrm{~m}$ length and $40 \mathrm{~m}$ height outcrop in which rocks are excellently exposed (Fig. 5). It is located in the cliff of the Andrín beach by the Cantabrian Sea (Asturias, Spain, NW Iberian Peninsula).

\subsubsection{Geological setting}

From the geological point of view this outcrop is located in the northeastern part of the Cantabrian Zone dominated by E-W trending structures (Fig. 4). This outcrop belongs to the north limb (backlimb) of the Cue anticline (Martínez-García et al. 1981) mapped by several authors (e.g., Martínez-Álvarez 1965; Martínez-García 1980; Marquínez 1989; Merino-Tomé et al. 2014; de Ana 2015; Bulnes et al. 2016) (Fig. 6a). The Cue anticline is a kilometre-scale, close fold with E-W direction, whose axis plunges to the east and its axial plane dips steeply to the north in the studied area. Both limbs of the Cue anticline dip to the north (Fig. 6b). The Cue anticline is interpreted as a ramp fold located in the hangingwall of a kilometre-length, E-W thrust that dips steeply to the north and whose hangingwall exhibits a southwards sense of motion.

The studied outcrop consists of red, nodular limestones, usually known as griotte facies (Fig. 5), that belong to the upper part of the Alba Fm., Lower Carboniferous (Martínez-García et al. 1981). The fact that these limestones were well bedded allowed carrying out a detailed structural interpretation of the point cloud using the 3D Stereo VDT software, estimate orientations of beds and structural elements, and measure bed thickness. The description of the main structural features of this outcrop presented below is based on the geological interpretation carried out using the 3D Stereo VDT software.

\subsubsection{Methodology and data collection}

A set of 58 HDR (High Dynamic Range) photographs (Fig. 7a) (built using either five or three shots for each image), taken in 2017 in the field using a conventional photographic camera, was used to construct the point cloud. 
The final point cloud consisted of 0.97 million points (Fig. 8). In order to obtain proper 3-D coordinates for the geological features interpreted in the point cloud, as well as proper measurements of plane and line orientations and lengths, the point cloud was referenced to its geographical position with its appropriate orientation and dimensions. To georeference the point cloud, coordinates of three ground control points (GCP) along the studied area were taken in the field using a combination of total station and differential GPS, and were subsequently processed using the software VisualSFM. To estimate the error, the point to point comparison method (Fonstad et al. 2013) was used. This consisted of using ten check points recorded in the field and left out of the point cloud generation procedure. Both the control and check points used were natural points easy to recognize such as intersections between beds and joints, changes in rock colour, significant topographic features, etc. These points were taken evenly spread along the outcrop to cover the whole scene and distributed at different depths of view. The root mean square error (RMSE) estimated was $24 \mathrm{~cm}$ and the mean deviation was $9 \mathrm{~cm}$. This example illustrates that the CAVE version of 3D Stereo VDT software allows the user to visualize and interpret point clouds obtained from traditional photographs of outcrops. Point clouds constructed using data from LIDAR / TLS and Unmanned Aerial Vehicles (UAVs) (Bemis et al. 2014; Fernández-Lozano and Gutiérrez-Alonso 2016) can also be visualized and interpreted from the geological point of view using 3D Stereo VDT.

\subsubsection{Outcrop description from the point cloud interpretation}

The main structural element of the outcrop is a decametre-scale anticline-syncline pair well exposed in the northeast portion of the outcrop (Fig. 8). These folds are cut and offset by a decametre-scale fault that divides the outcrop in two parts. The southeastern limb of the anticline dips about $25^{\circ}$ to the southeast, whereas its northwestern limb (inverted and common with the syncline) and the northwestern limb of the syncline dip around $60^{\circ}$ also to the southeast. The axial planes of these folds strike approximately ENE-WSW; the anticline axial surface dips about $80^{\circ}$ to the south-southeast, whereas the syncline axial surface dips around $55^{\circ}$ also to the south-southeast. These strike and dip values were estimated by obtaining coordinates of several points belonging to the axial surface traces of the folds, mapped on the point cloud, and fitting planes through them using a method called moment of inertia analysis (Fernández 2005). This method was implemented in an in-house script, within Matlab environment, developed by one of the authors of this paper (Hodei Uzkeda). The axes of both folds are subhorizontal, in general plunging less than $20^{\circ}$ to the east, being $\mathrm{N} 070^{\circ} \mathrm{E}$ the mean direction. They are relatively close folds, although the syncline becomes tighter towards the west-southwest, in the southern fault block. Second-order folds occur along the limbs of these major folds. They are small, around $1 \mathrm{~m}$ wavelength, detachment folds. The fault mentioned above exhibits a NW-SE strike (around $\left.\mathrm{N} 060^{\circ} \mathrm{W}\right)$, is almost vertical $\left(85^{\circ}\right.$ dip to the southwest) and it seems to sink the southwestern block a few metres. Again, the fault orientation was estimated by obtaining coordinates of several points along the fault trace, mapped on the point cloud, and fitting planes through them.

\subsubsection{Discussion of the results obtained from the Andrín outcrop}

The spatial and temporal relationships between the north-vergent folds mapped using the point cloud (Figs. 5 and 8) and the larger-scale, south-vergent Cue anticline (Fig. 6) have been previously discussed in Bulnes et al. (2016). These authors propose three hypotheses based exclusively on field data.

1) The folds could have been developed before amplification of the Cue anticline, disconnected from it and related to the two thrusts recognized in the vicinity of the outcrop, one directed towards the north and another directed towards the south (Fig. 6b). The folds could have developed either in an accommodation zone of intense ductile deformation at the upper tip of the south-directed thrust, or due to the motion of the north-directed thrust.

2) The folds could also be the result of layer-parallel shortening in early stages prior to the Cue anticline amplification. The present-day vergence of these folds would result from the tilting suffered by the layers in the backlimb of the Cue anticline developed afterwards, so that these folds would have originated with subvertical or steeply dipping axial planes.

3) The folds could have originated during the development of the Cue anticline in a relatively ductile retro-vergence zone located on the backlimb of the Cue anticline. In this sense, the general structure would be similar to some extent to some natural (e.g. Alonso and Teixell 1992) and experimental (e.g. Huiqi et al. 1992) ramp folds developed in the hangingwall of thrusts, which include backthrusts or shear zones in their backlimbs.

The construction of a point cloud covering a much wider region of the Cue anticline, especially in areas with a large number of minor folds, would provide additional data from inaccessible areas that could be essential to check the three hypothesis and decipher which one fits better the data.

In order to determine the possible errors made in the geological interpretation of the point cloud, strike and dip measurements of beds, as well as measurements of bed thickness, taken on the point cloud were compared with field measurements taken on the accessible portions of the outcrop (Fig. 9). The RMSE, expressed as the angle between the bedding dip data measured in the field and on the cloud, is $7.5^{\circ}$ and the average deviation is $1.7^{\circ}$. In relation to bed thickness, the RMSE is $7.2 \mathrm{~cm}(8.2 \%)$ and the average deviation is $3.3 \mathrm{~cm}(3.5 \%)$. The dip discrepancies were similar 
to those obtained by Cawood et al. (2017) when comparing orientations measured in the field with those of fitted surfaces extracted from point clouds created by photogrammetry in areas with an adequate coverage. Considering the errors due to the irregularity of the bedding surfaces, those made when carrying out the geological interpretations and measurements, those derived from the measurement instruments, and those derived from the point cloud construction, it would be reasonable to conclude that the errors on the orientations and thickness of bedding surfaces support the accuracy of the point cloud constructed for geological purposes and that of the 3D Stereo VDT software created for geological interpretation.

A rigorous fold analysis requires the construction of profiles perpendicular to the fold axes. The construction of fold profiles using graphical techniques has been carried out by hand for many decades and more recently with specific software because it is a laborious task, particularly when a lot of detail is required. The use of a point cloud is a clear advantage because allows a fast construction of fold profiles. A section across a metre-scale anticline obtained from the interpretation of a field photograph, taken as much perpendicular as possible to the anticline axis (Fig. 10a), is compared to an anticline profile extracted from the point cloud. The comparison is based on determining the fold class using Ramsay (1967) diagram employing both cross sections (Figure 10b). To carry out the classification, isogons have been drawn on the photogeological interpretation and on the point-cloud derived profile (Figs 10c and 10d). The results obtained from both sections were similar in the case of the southeast fold limb, which belonged to class 1C (i.e., thickened hinge folds) tending to class 2 (i.e., similar folds) (Fig. 10b). However, this was not the case for the northwest fold limb. The northwest fold limb in the geological profile derived from the point cloud was also classified as class $1 \mathrm{C}$ tending to class 2 . In contrast, the geological section derived from the photointerpretation pointed to an approximately class 1B fold limb. Three different issues arose when comparing the results obtained from the geological interpretation of a conventional field photograph with those from the $3 \mathrm{D}$ geological interpretation of the point cloud.

1) Regarding the anticline sections, the southeast fold limb is thinner than the northwest one and the hinge thickness is similar to that of the northwest limb in the geological section derived from the photointerpretation (Fig. 10c). However, both limbs have a relatively similar thickness and the hinge is thicker than the fold limbs in the geological profile derived from the point cloud interpretation (Fig. 10d).

2) Regarding the isogons, the anticline exhibits a convergent pattern towards the inner fold core in both the photograph-derived cross section and in the point cloud-derived profile. However, the isogon pattern on the photointerpretation (Fig. 10c) is more irregular than that on the point cloud interpretation (Fig. 10d).

3) Regarding the fold class, the anticline limbs belong to different classes according to the analysis of the geological section obtained from the photointerpretation, whereas both anticline limbs belong to the same class according to the analysis of the geological profile obtained from the point cloud interpretation (Fig. 10b).

The cross-sectional geometry of the anticline, the isogon pattern and the classification of the fold limbs obtained from the point cloud make more sense from the geological point of view, and are more accurate and more reliable than those obtained from the field photograph. This is an expected result because the section derived from the field photograph is not strictly perpendicular to the anticline axis. In addition, other discrepancies between both are due to the uneven erosion of the outcrop that gave rise to an irregular morphology and made it difficult to obtain suitable views using conventional photographs.

\subsection{Aerial example: the Cacabillo outcrop}

The second example consists of an approximately $1.2 \mathrm{~km}^{2}$ region, with very good outcrop quality (Fig. 11). It is located to the north of a small locality called Cacabillo at the headwaters of the Sil river in the Cantabrian Mountains (León, Spain, NW Iberian Peninsula).

\subsubsection{Geological setting}

From the geological point of view the studied region belongs to the southwestern portion of the Cantabrian Zone close to the arc core where NW-SE trending structures predominate (Fig. 4). The studied area, displayed in various geological maps and cross sections (e.g., Navarro Vázquez and Rodríguez Fernández 1979; Bastida et al. 1984; Heredia, 1984; Bastida and Gutiérrez 1989; Merino-Tomé et al. 2014) (Fig. 12a), is located in the hinge zone of the Cacabillo anticline (Navarro Vázquez and Rodríguez Fernández 1979), also known as Puerto de Somiedo anticline (Bastida et al. 1984). This anticline is a NW-SE trending, kilometre-scale, tight fold that exhibits several second-order folds developed in its hinge. A subvertical, NW-SE trending fault of several kilometres length but small displacement occurs in the core of the Cacabillo/Puerto de Somiedo anticline, separating the southwest-dipping limb from the hinge and the northeast-dipping limb (Fig. 12b).

The rocks that crop out in the studied region belong to two Devonian stratigraphic units, which from bottom to top are: La Vid Gr. and Santa Lucía Fm. (Figs. 11 and 12). La Vid Gr. (Lower Devonian) is mainly composed of 
interbedded dolostones, slates, limestones and marls, whereas the Santa Lucía Fm. (Lower to Middle Devonian) is a limestone unit with sparse marls and slates (Navarro Vázquez et al. 1982). The distinct lithologies within these two stratigraphic units exhibited a different response in the point cloud in terms of slope and outcrop quality, which facilitated mapping their boundaries. In addition, the presence of well-stratified portions of the stratigraphic sequence allowed a detailed interpretation of the virtual outcrop from the structural point of view using the 3D Stereo VDT software (Fig. 13). Moreover, orientation of some beds and structural elements could be estimated accurately. Below it is the description of the most important structural features of this outcrop on the basis of the geological interpretation carried out using 3D Stereo VDT.

\subsubsection{Methodology and data collection}

Similarly to taking pictures using a photographic camera, a number of images (80) of the study region were taken from different viewpoints using the "save as" option in Google Earth (Fig. 7b). They were subsequently employed to build the point cloud. The Google Earth images of this region used to construct the point cloud were acquired in 2017. The resulting point cloud had 6.02 million points (Fig. 13). To georeference the point cloud in its correct geographical position taking into account its appropriate orientation and dimensions, coordinates of four GCP were measured along the area. These points were extracted from Google Earth as some parts of the outcrop were virtually inaccessible, which prevented taking them directly on the field. This was a vital issue as it allowed us an approximate identification of 3D coordinates of interpreted geological features on the point cloud, as well as accurate measurements of plane and line orientations and lengths. The software VisualSFM was used to carry out this step. The coordinates of five check points, measured on the Google Earth images but not used during the point cloud generation procedure, were used to estimate the error using the point to point comparison method (Fonstad et al. 2013). These points were taken at even intervals along the outcrop to cover the whole scene and distributed at different depths of view. The RMSE estimated was $4.0 \mathrm{~m}$ and the mean deviation was $1.5 \mathrm{~m}$. This example shows how point clouds derived from Google Earth may be loaded and interpreted in the CAVE using the 3D Stereo VDT software (Fig. 1a) which is capable of dealing with point clouds derived from aerial or other type of long range photographs. The main advantage of working with Google Earth images instead of using traditional aerial photographs is that the user has control of the orientation, position and level of detail of the images. This flexibility allows, for example, creating point clouds with high point density for areas of special interest, such as zones where small features (metre- to decametrescale, depending on the available image resolution) predominate. The employment of Google Earth images may also be helpful when working in remote areas where no aerial photographs, ortophotographs or digital elevation models (DEM) are available or in inaccessible regions. In fact, the point cloud presented corresponds to a mountainous region difficult to access except for experienced climbers.

\subsubsection{Outcrop description from the point cloud interpretation}

The main structural elements of the studied region are close to relatively open, hectometre-scale folds, in particular two major anticlines and two synclines (Fig. 13). The axial surfaces of these major folds dip from $80^{\circ}$ to vertical either to the northeast or to the southwest, and strike approximately NW-SE, between $\mathrm{N} 030^{\circ} \mathrm{W}$ and $\mathrm{N} 040^{\circ} \mathrm{W}$ (Fig. 14). With regard to bedding, we have only been able to measure the orientation of the stratification surfaces on the northeast limbs of the folds due to the outcrop shape. The strike of these beds ranges from $\mathrm{N} 045^{\circ} \mathrm{W}$ to $\mathrm{N} 015^{\circ} \mathrm{E}$ with dips from $30^{\circ}$ to $45^{\circ}$ to the northeast. All these strike and dip values were calculated by fitting planes along coordinates of points belonging to axial surface and bedding traces, mapped on the point cloud, using the moment of inertia analysis (Fernández 2005) implemented in an in-house script within Matlab environment. There are also several eastward-directed major thrusts, whose strikes are approximately NNE-SSW. These thrust faults are deformed by the folds described above and show staircase geometries with flats developed within the incompetent units and ramps cutting across competent units. Additionally, some minor planar faults with apparent decametre-scale displacements are particularly visible in the northeast limb of the easternmost anticline. These faults cut and offset the major fold limbs and, in some cases, the thrusts. These minor faults strike around N-S (between $\mathrm{N} 010^{\circ} \mathrm{W}$ and $\mathrm{N} 035^{\circ} \mathrm{E}$ ) and their dip ranges from $40^{\circ}$ to $80^{\circ}$ to the west (Fig. 14). Apart from the faults described above, other minor faults in terms of cartographic extent and displacement, cut and offset the hinge and southwest limb of the westernmost major syncline. These minor faults exhibit NW-SE strikes (from $\mathrm{N} 030^{\circ} \mathrm{W}$ to $\mathrm{N} 050^{\circ} \mathrm{W}$ ) and dips above $55^{\circ}$ either to the northeast or to the southwest. Again, the orientation of these minor faults was determined through fitting planes along coordinates of points belonging to the fault traces mapped on the point cloud.

\subsubsection{Discussion of the results obtained from the Cacabillo outcrop}

The geological structures mapped on the virtual outcrop analysed allowed us to provide some ideas on the main features of the Cacabillo/Puerto de Somiedo anticline and on the structural history of the region. The folds recognized in the point cloud might be interpreted as second order folds associated with the larger-scale Cacabillo/Puerto de Somiedo anticline, since the strike and dip of their axial planes, and at least those of one of their limbs, is consistent with the map-scale orientation of the Cacabillo/Puerto de Somiedo anticline. In addition, the asymmetry of these 
second order folds is consistent with its structural position on the northeast limb of the Cacabillo/Puerto de Somiedo anticline. Thus, the Cacabillo/Puerto de Somiedo anticline is not a parallel fold but corresponds to a structure whose core is thickened mainly by second order folds accompanied by thrusts. In relation to the structural history of the region, the thrusts involve relatively small displacements, duplicate stratigraphic units, and occurred before the folds, or perhaps simultaneously, but in any case the folds were active for longer so that they ended up folding the thrusts. The minor faults, that cut and offset especially the limbs of the folds, developed after the thrusts although its structural relationship with the traces of the minor folds is unclear.

The projection of the virtual outcrop interpretation onto different section planes was compared to a field crosssection constructed by Bastida et al. (1984) (Fig. 15a). The strike of the section planes chosen is perpendicular to that of the axial planes measured on the point cloud and plotted in Fig. 14; the orientation of these axial planes is consistent with those presented in previous regional geological maps and sections across the area (Bastida et al. 1984; Heredia, 1984). Section planes with different inclinations were tested as it was not possible to measure fold axes on the point cloud, and in addition, Bastida et al. (1984) mentioned the occurrence of fold axes of variable plunge near the study area. The overall geometry of the structures is similar, especially when comparing the field interpretation (Fig. 15a) and the vertical section (Fig. 15b). In all the cross sections beds maintain approximately constant thickness, except for a thick ductile layer located at the lower part of the Santa Lucia Fm. that exhibits a thickness increase in the hinge zone of the folds located at the southwest part of the sections. Thus, folds are approximately parallel. The apparent structural relief of the folds and the ductile layer thickness in the hinge zone decrease as the section plane becomes more perpendicular to the fold axes, and therefore, they become closer to the actual values. The major difference is the scale of the sections. Since the scale of the point cloud is correct as it was validated with check points, the scale of the field interpretation would have been overestimated and might mislead to incorrect values if used, for instance, to attempt to measure bed thicknesses, lengths, and/or dips, fault slips and/or cross-sectional areas. Thus, the point cloud interpretation would be more reliable for taking these measurements.

Unfortunately, it was not possible to determine to what extent this point cloud and its geological interpretation were correct or the degree of error they had. We could not compare the orientation of the structural elements of folds and faults obtained from the point cloud with values measured directly in the field, since, as mentioned above, most of the outcrop was inaccessible. However, the values of strikes and dips of axial surfaces of folds, bedding and faults presented above, measured on the virtual outcrop, could hardly have been obtained in the field.

\section{Conclusions}

3D Stereo VDT, a new in-house software for CAVE platforms, proved to be a valuable tool for the interpretation of virtual outcrops from the geological point of view. The full potential of this software was demonstrated through its application to two examples of folded and faulted upper Palaeozoic sedimentary rocks from the north and south portion of the Cantabrian Zone (NW Iberian Peninsula). The two point clouds employed came from different sources. One of them corresponded to a relatively small outcrop (metre-scale) located on a coastal cliff, whose point cloud was constructed using close range terrestrial methods (i.e. field photographs). The other outcrop was a valley slope outcrop (hectometre-scale) situated in a mountainous area, whose point cloud was constructed using Google Earth images (i.e. an aerial example). The geological interpretations of the two virtual outcrops were carried out in a short time because the 3D Stereo VDT commands are relatively intuitive and easy to use. 3D Stereo VDT software facilitated detailed geological interpretations because it supplied correct views of the structures that eased the structural interpretation in spite of the irregular morphology of the outcrops. In addition, 3D Stereo VDT allowed the correct correlation of the different stratigraphic horizons along the outcrops even though beds are folded, repeated by thrusts, and cut and offset by faults. The 3D geological interpretations were used to calculate dips and strikes of geological elements by fitting planes to points belonging to their cartographic traces mapped on the point clouds. A measurement tool implemented in 3D Stereo VDT permitted the calculation of bed thickness to compare beds in different portions of the outcrop. The comparison of point cloud and field measurements supports the accuracy of the point cloud and their geological interpretations.

The new 3D geological interpretations of the Andrín and Cacabillo outcrops made possible to better understand the main characteristics of the mapped structures, as well as their spatial and temporal relationships with the largerscale anticlines to which the studied outcrops belong. The Andrín outcrop consists of an anticline-syncline pair offset by a subvertical fault; the folds belong to class $1 \mathrm{C}$, are close and north-vergent. The Cacabillo outcrop is made up of a fold train including two anticlines and two synclines that bend thrust faults; the folds are approximately parallel, close to open and exhibit subvertical axial surfaces. Bed boundaries, faults and fold axial surfaces interpreted on the point clouds were the basis for the generation of geological cross-sections, but they can be also employed to construct $3 \mathrm{D}$ geological models and/or geological maps.

Geological interpretation of virtual outcrops should be promoted amongst the scientific community because it helps understanding them since they are visualized and interpreted in 3D and, in addition, it supplies 3D geological datasets. This has the advantage of allowing data extraction and, in turn, quantitative analysis of even remote, inaccessible portions of the structures. Moreover, it has applications in both academia and industry. For example, use as geological field teaching aids, exploratory scientific interest and as 3D data sets used for hydrocarbon analogue 
analysis.

\section{Acknowledgments}

We acknowledge financial support by research project CGL2015-66997-R: “Aplicación del análisis del plegamiento a la investigación de recursos geológicos" (AAPLIREGE) funded by the Spanish Ministry for Economy and Competitiveness and the European Fund for Regional Development (FEDER), research project FC-GRUPINIDI/2018/000216 (Ayudas a organismos públicos de investigación para apoyar la actividad que desarrollen sus grupos de investigación en el Principado de Asturias en el periodo 2018-2020) funded by the Principado de Asturias, and research contract CN-16-014: "Convenio específico para la realización de un trabajo de investigación post-doctoral en la disciplina de Geología" under the framework agreement between Repsol Exploración S.A. and the University of Oviedo. Comments by G. Gutiérrez-Alonso, N. Heredia and B. Burnham substantially improved the manuscript. We thank Changchang $\mathrm{Wu}$ for permission to use the software VisualSFM, the Visual Computing Lab-ISTI-CNR for permission to use MeshLab, and R.Allmendinger and N. Cardozo for permission to use Stereonet. We thank I. Moriano for her tests of the initial versions of the 3D Stereo VDT software and J.G. Antuña for maintaining the software for structural interpretation and modelling.

\section{References}

Aller, J., Álvarez-Marrón, J., Bastida, F., Bulnes, M., Heredia, N., Marcos, A., Pérez-Estaún, A., Pulgar, F. J. A., \& Rodríguez-Fernández, R. (2004). Estructura, deformación y metamorfismo (Zona Cantábrica). In J. A. Vera (Ed.), Geología de España (pp. 42-49). Madrid: Sociedad Geológica de España-Instituto Geológico y Minero de España.

Alonso, J. L., Álvarez-Marrón, J., Aller, J., Bastida, F., Farias, P., Marcos, A., Marquínez, J., Pérez-Estaún, A., \& Pulgar, J. A. (1992). Estructura de la Zona Cantábrica. In J. G. Gutiérrez Maco, J. Saavedra, \& I. Rábano (Eds.), Paleozoico Inferior de Ibero-América (pp. 423-434). Badajoz: Universidad de Extremadura.

Alonso, J. L., Marcos, A., \& Suárez-Rodríguez, A. (2009). Paleogeographic inversion resulting from large out of sequence breaching thrusts: the León Fault (Cantabrian Zone, NW Iberia). A new picture of the external Variscan thrust belt in the Ibero-Armorican Arc. Geologica Acta, 7(4), 451-473.

Alonso, J. L., \& Teixell, A. (1992). Forelimb deformation in some natural examples of fault-propagation folds. In K. McClay (Ed.), Thrust Tectonics (pp. 175-180). London: Chapman, \& Hall.

Banerjee, S., \& Mitra, S. (2004). Remote surface mapping using orthophotos and geologic maps draped over digital elevation models: Application the Sheep Mountain anticline, Wyoming. AAPG Bulletin, 88(9), 1227-1237.

Bastida, F., \& Gutiérrez, G. (1989). Síntesis cartográfica de las unidades occidentales de la Zona Cantábrica. Trabajos de Geología, 18, 117125.

Bastida, F., Marcos, A., Pérez-Estaún, A., \& Pulgar, J. A. (1984). Geometría y evolución estructural del Manto de Somiedo (Zona Cantábrica, NO España). Boletín Geológico y Minero de España, XCV(VI), 517-539.

Bellian, J. A., Kerans, C., \& Jennette, D. C. (2005). Digital outcrop models: Applications of terrestrial scanning lidar technology in stratigraphic modeling. Journal of Sedimentary Research, 75(2), 166-176.

Berger, Z., Lee Williams, T.H., \& Anderson, D. W. (1992). Geologic stereo mapping of geologic structures with SPOT satellite data. AAPG Bulletin, 76(1), 101-120.

Bemis, S. P., Micklethwaite, S., Turner, D., James, M. R., Akciz, S., Thiele, S. T., \& Bangash, H. A. (2014). Ground-based and UAV-based photogrammetry: A multi-scale, high-resolution mapping tool for structural geology and paleoseismology. Journal of Structural Geology, 69, 163-178.

Biondi, B. L. (2006). 3D seismic imaging (pp. 224). Tulsa: Society of Exploration Geophysicists. Investigations in Geophysics Series, 14.

Buckley, S. J., Howell, J. A., Enge, H. D., \& Kurz, T. H. (2008). Terrestrial laser scanning in geology: data acquisition, processing and accuracy considerations. Journal of the Geological Society, 165(3), 625-638.

Bulnes, M., Poblet, J., de Ana, A., \& Masini, M. (2016). Comportamiento de las calizas "griotte" carboníferas frente a deformaciones compresivas en dos localidades de la Zona Cantábrica (NO de la Península Ibérica): resultados preliminares. Trabajos de Geología, 36, 61-80.

Carrivick, J. L., Smith, M. W., \& Quincey, D. J. (2016). Structure from Motion in the Geosciences (pp. 197). Chichester: John Wiley, \& Sons.

Casini, G., Hunt, D. W., Monsen, E., \& Bounaim, A. (2016. Terrestrial laser scanning in geology: data acquisition, processing and accuracy considerations. AAPG Bulletin, 100(1), 41-61.

Cawood, A. D., Bond, C. E., Howell, J. A., Butler, T. W. H., \& Totake, Y. (2017). LiDAR, UAV or compass-clinometer? Accuracy, coverage and the effects on structural models. Journal of Structural Geology, 98, 67-82.

Corradetti, A., Tavani, S., Russo, M., Cazo Arbués, P., \& Granados, P. (2017). Quantitative analysis of folds by means of orthorectified photogrammetric 3D models: A case study from Mt. Catria, northern Apennines, Italy. The Photogrammetric Record, 32(160), $480-496$.

de Ana, A. (2015. Estructura de los materiales paleozoicos entre las localidades de Llanes y Andrín (Unidad del Ponga, Zona Cantábrica). MSc thesis. Universidad de Oviedo, Spain. 37 pages.

Dhont, D., Luxey, P., \& Chorowicz, J. (2005). 3-D modeling of geologic maps from surface data. AAPG Bulletin, 89(11), 1465-1474.

Dijkerman, H. C., Milner, A. D., \& Carey, D. P. (1999). Motion parallax enables depth processing for action in a visual form agnosic when binocular vision is unavailable. Neuropsychologia, 37(13), 1505-1515.

Dueholm, K. S., Garde, A. A., \& Pedersen, A. K. (1993). Preparation of accurate geological and structural maps, cross-sections or block diagrams from colour slides, using multi-model photogrammetry. Journal of Structural Geology, $15(7), 933-937$.

Durand, K., Lécuyer, R., \& Frichtel, M. (2003). Representation of the third dimension: The use of perspective cues by 3- and 4-month-old infants. Infant Behavior, \& Development, 26(2), 151-166.

Fernández, 0. (2005). Obtaining a best fitting plane through 3D georeferenced data. Journal of Structural Geology, 27(5), 855-858.

Fernández-Lozano, J., \& Gutiérrez-Alonso, G. (2016). Aplicaciones geológicas de los drones. Revista de la Sociedad Geológica de España, 29, 89-105.

Fonstad, M. A., Dietrich, J. T., Courville, B. C., Jensen, J. L., \& Carbonneau, P. E. (2013). Topographic structure from motion: A new development in photogrammetric measurement. Earth Surface Processes and Landforms, 38, 421-430.

Gargollo, F. E. (2014). 3D Stereo VDT. User Manual. Cave version 1.0. Internal Report. Universidad de Oviedo, Oviedo, Spain. 16 pages. 
Gonzaga Jr., L.,Veronez, M. R., Kannenberg, G. L., Nunes Alves, D., Gomes Santana, L., de Fraga, J. L., Campos Inocencio, L., Vieira de Souza, L., Marson, F., Bordin, F., Tognoli, F. M. W., Senger, K., \& Cazarin., C.L. (2018). A multioutcrop sharing and interpretation system. IEEE Geoscience and Remote Sensing Magazine, 6(2), 8-16.

Heredia, N. (1984). La estructura de la Escama de Villar de Vildas (Manto de Somiedo, Zona Cantábrica). Trabajos de Geología, $14,65-79$.

Howard, I. P., \& Rogers, B. J. (2016). Binocular vision and stereopsis (pp. 736). Oxford: Oxford University Press.

Huiqi, L McClay, K. R., \& Powell, D. (1992). Physical models of thrust wedges. In K. McClay (Ed.), Thrust Tectonics (pp. 71-81). London: Chapman, \& Hall.

Julivert, M. (1971). Décollement tectonics in the Hercynian Cordillera of NW Spain. American Journal of Science, 270, 1-29.

Julivert, M. (1979). A cross-section through the northern part of the Iberian Massif: its position within the Hercynian fold belt. Krystalinikum, 14, 51-67.

Julivert, M. (1981). A cross-section through the northern part of the Iberian Massif: its position within the Hercynian fold belt. Geologie en Minbouw, 60, 107-128.

Julivert, M. (1983). La estructura de la Zona Cantábrica. In J. A Comba (Ed.), Geología de España. Libro Jubilar J. M. Ríos, Tomo I (pp. 339381). Madrid: Instituto Geológico y Minero de España.

Julivert, M., Fontboté, J. M., Ribeiro, A., \& Conde, L. E. (1972). Mapa Tectónico de la Península Ibérica y Baleares, escala 1:1000000. Instituto Geológico y Minero de España, Madrid, Spain.

Lotze, F. (1971). Zur gliederung der varisziden der Iberischen Meseta. Geotektonische Forschungen, 6, 78-92.

Martín, S., Uzkeda, H., Poblet, J., Bulnes, M., \& Rubio, R. (2013). Construction of accurate geological cross-sections along trenches, cliffs and mountain slopes using photogrammetry. Computers, \& Geosciences, 51, 90-100.

Marquínez, J. (1989). Mapa geológico de la Región del Cuera y los Picos de Europa. Trabajos de Geología, 18, $137-144$.

Martínez Álvarez, J. A. (1965). Rasgos geológicos de la zona oriental de Asturias (pp. 132). Oviedo: Instituto de Estudios AsturianosDiputación Provincial de Oviedo.

Martínez-García, E. (1980). Mapa geológico de España. Escala 1:50.000. Hoja: 32 (16-04) Llanes. Instituto Geológico y Minero de España, Madrid, Spain.

Martínez-García, E., Corrales, I., Valladares, I., Méndez, I., Ramírez del Pozo, J., van Ginkel, A. C., Lamolda, M.; Moreno de Castro, E., \& Marcos, A. (1981). Memoria del mapa geológico de España. Escala 1:50.000. Hoja: 32 (16-04) Llanes. Instituto Geológico y Minero de España, Madrid, Spain. 40 pages.

Marx Bellina, G., Wohnrath Tognoli, F. M., \& Veronez, M. R. (2016). Outcrop explorer: a point-based system for visualization and interpretation of lidar digital models. Brazilian Journal of Cartography, 68(6), 1211-1219.

McCaffrey, K. J. W., Hodgetts, D., Howell, J., Hunt, D., Imber, J., Jones, R. R., Tomasso, M., Thurmond, J., \& Viseur, S. (2010). Virtual fieldtrips for petroleum geoscientists. In B. A. Vining, \& S. C. Pickering (Eds.), Petroleum Geology: From mature basins to new frontiers Proceedings of the 7th Petroleum Geology Conference (pp. 19-26). 7th Petroleum Geology Conference, London, UK.

McConnell, D. A., Kattenhorn, S. A., \& Benner, L. M. (1997). Distribution of fault slip in outcrop-scale fault-related folds. Journal of Structural Geology, 19(3-4), 257-267.

Merino-Tomé, O., Suárez-Rodríguez, A., \& Alonso, J. L. (2014). Mapa Geológico Digital Continuo a Escala 1:50.000 de la Zona Cantábrica (Plan GEODE). http://www.igme.es.

Micklethwaite, S., Turner, D., Vasuki, Y., Kovesi, P., Holden, E.-J. \& Lucieer, A. (2012). Mapping from an Armchair: Rapid, high-resolution mapping using UAV and computer vision technology. Proceedings of Structural Geology and Resources, 130-133.

Minisini, D., Wang, M., Bergman, S. C., \& Aiken, C. (2014). Geological data extraction from lidar 3-D photorealistic models: A case study in an organic-rich mudstone, Eagle Ford Formation, Texas. Geosphere, 10(3), 610-626.

Moriano, I., Martín, S., Poblet, J., \& Bulnes, M., in prep. Accurate construction and geological interpretation of virtual outcrops.

Navarro Vázquez, D., \& Rodríguez Fernández, R. (1979). Mapa geológico de España. Escala 1:50.000. Hoja: 101 Villablino. Instituto Geológico y Minero de España, Madrid, Spain.

Navarro Vázquez, D. ENADIMSA, Departamento de Paleontología de la Universidad de Oviedo, \& Rodríguez Fernández, R. (1982). Memoria del mapa geológico de España. Escala 1:50.000. Hoja: 101 Villablino. Instituto Geológico y Minero de España, Madrid, Spain. 56 pages.

Olariu, M. I., Aiken, C. L. V., Bhattacharya, J. P., \& Xu, X. (2011). Interpretation of channelized architecture using three-dimensional photo real models, Pennsylvanian deep-water deposits at Big Rock Quarry, Arkansas. Marine and Petroleum Geology, 28(6), 1157-1170.

Pérez-Estaún, A., \& Bastida, F. (1990). Cantabrian Zone: structure. In R. D. Dallmeyer, \& E. Martínez-García (Eds.), Pre-Mesozoic Geology of Iberia (pp. 55-69). Berlin: Springer-Verlag.

Pérez-Estaún, A., Bastida, F., Alonso, J. L., Marquínez, J., Álvarez-Marrón, J., Marcos, A., \& Pulgar, F. J. A. (1988). A thin-skinned tectonics model for an arcuate fold and thrust belt: the Cantabrian Zone (Variscan Ibero-Armorican Arc). Tectonics, 7, $517-537$.

Pringle, J. K., Westerman, A. R., Clark, J. D., Drinkwater, N. J., \& Gardiner, A.R. (2004). 3D high-resolution digital models of outcrop analogue study sites to constrain reservoir model uncertainty: an example from Alport Castles, Derbyshire, UK. Petroleum Geoscience, 10(4), 343352.

Ramsay, J.G. (1967). Folding and fracturing of rocks (pp. 568). New York: McGraw-Hill.

Rogers, B. J., \& Bradshaw, M. F. (1993). Vertical disparities, differential perspective and binocular stereopsis. Nature, 361, $253-255$.

Savage, J. F. (1979). The Hercynian orogeny in the Cantabrian mountains, Northern Spain. Krystalinikum, 14, 91-108.

Savage, J. F. (1981). Geotectonic cross-section through the Cantabrian mountains, northern Spain. Geologie en Mijnbouw, 81, 3-5.

Sørensen, E. V., \& Dueholm, M. (2018). Analytical procedures for 3D mapping at the Photogeological laboratory of the Geological Survey of Denmark and Greenland. Geological Survey of Denmark and Greenland Bulletin, 41, 99-104.

Sørensen, E. V., \& Guarnieri, P. (2018). Remote geological mapping using 3D photogrammetry: an example from Karrat, West Greenland. Geological Survey of Denmark and Greenland Bulletin, 41, 63-66.

Svennevig, K., Guarnieri, P., \& Stemmerik, L. (2015). From oblique photogrammetry to a 3D model - Structural modeling of Kilen, eastern North Greenland. Computers, \& Geosciences, 83, 120-126.

Swanston, M. T., \& Wade, N. J. (2001). Visual perception: an introduction (pp. 294). Philadelphia: Psychology Press.

Tavani, S., Granado, P., Corradetti, A., Girundo, M., Iannace, A., Arbués, P., Muñoz, J.A. \& Mazzoli, S. (2014). Building a virtual outcrop, extracting geological information from it, and sharing the results in Google Earth via OpenPlot and Photoscan: An example from the Khaviz Anticline (Iran). Computers \& Geosciences, 63, 44-53.

Triggs, B., McLauchlan, P. F., Hartley, R. I., \& Fitzgibbon, A. W. (2000). Bundle adjustment - A modern synthesis. In B. Triggs, A. Zisserman, \& R. Szeliski (Eds.), Vision Algorithms: Theory and Practice (pp. 298-372). Berlin: Springer-Verlag.

Trinks, I., Clegg, P., McCaffrey, K., Jones, R., Hobbs, R., Holdsworth, B., Holiman, N., Imber, J., Waggott, S., \& Wilson, R. (2005). Mapping and analysing virtual outcrops. Visual Geosciences, 10(1), 13-19.

Uzkeda, H., Poblet, J., \& Bulnes, M. (2010). A geometric and kinematic model for double-edge propagating thrusts involving hangingwall and footwall folding. An example from the Jaca-Pamplona Basin (Southern Pyrenees). Geological Journal, 45(5-6), 506-520. 
Vasuki, Y., Holden, E. J., Kovesi, P., \& Micklethwaite, S. (2014). Semi-automatic mapping of geological Structures using UAV-based photogrammetric data: An image analysis approach. Computers \& Geosciences, 69, 22-32.

Wang, X., Zou, L., Shen, X., Ren, Y., \& Qin, Y. (2017). A region-growing approach for automatic outcrop fracture extraction from a threedimensional point cloud. Computers, \& Geosciences, 99, 100-106

Wu, C. (2013). Towards linear-time incremental structure from motion. Proceedings of the 3DV 2013, Seattle, USA, 127-134.

Wu, C., Agarwal, S., Curless, B., \& Switz, S.M. (2011). Multicore bundle adjustment. Proceedings of the IEEE CVPR 2011, Colorado Springs, USA, 3057-3064.

Xu, X., Aiken, C. L., Bhattacharya, J. P., Corbeanu, R. M., Nielsen, K. C. McMechan, G. A., \& Abdelsalam, M. G. (2000). Creating virtual 3-D outcrop. The Leading Edge, 19(2), 197-202.

Xu, X., Bhattacharya, J. P., Davies, R. K., \& Aiken, C. L. V. (2001). Digital geologic mapping of the Ferron Sandstone, Muddy Creek, Utah, with GPS and reflectorless rangefinder. GPS Solutions, 19(1), 15-23. 


\section{Figure captions}

Fig. 1 a Photograph of a user wearing shutter glasses with the in-built positioning system and interpreting the Cacabillo virtual outcrop shown in Fig. 13 within the CAVE and employing the software 3D Stereo VDT. b Specific controller (Wiimote + Nunchuk) to carry out the geological interpretation. Infrared cameras track the user movement.

Fig. 2 Simplified workflow for the creation and geological interpretation of photorealistic virtual outcrops in order to construct cross sections and 3D models using the CAVE version of the 3D Stereo VDT software

Fig. 3 Navigation diagram of the 3D Stereo VDT software for CAVE. The four main controls are displayed within circles at the upper portion of the figure. The different square dark grey controls displayed on the central left part of the figure refer to the different transformations that can be applied to lines. The square light grey controls on the central right part of the figure correspond to controller configuration

Fig. 4 Structural sketch of the Cantabrian Zone (Variscan foreland fold and thrust belt) in the core of the Ibero-Armorican or Asturian Arc showing the location of the two selected outcrops: Andrín (close-range example, N43.41 ${ }^{\circ}, \mathrm{W} 4.71^{\circ}$ ) and Cacabillos (aerial example, N42.99 ${ }^{\circ}$, W6.20 $0^{\circ}$ ). Simplified from Pérez-Estaún et al. (1988)

Fig. 5 Picture of the Andrín outcrop taken with a conventional photographic camera in 2017. The height of the most elevated point in the foreground mountain with respect to the beach sand is approximately $9 \mathrm{~m}$

Fig. 6 a Geological map and $\mathbf{b}$ geological section across the eastern portion of the Cue anticline showing the position of the Andrín outcrop. The cross section line is indicated in a. Modified from de Ana (2015)

Fig. 7 a Andrín and b Cacabillo outcrops' sparse point clouds showing the camera position used for taking the images. The scale is approximate

Fig. 8 Horizontal views a to the SW, b to the WSW, c to the W, and $\mathbf{d}$ to the SSW of the Andrín outcrop's point cloud and interpretation of key beds, main fold axial surfaces and faults carried out using the CAVE version of the software 3D Stereo VDT. The green planes indicate the position of the data used to compare field and virtual orientation measurements. The white square in a indicates the position of Fig. 10 . See Figs. 4 and 6 for location of the outcrop

Fig. 9 a Equal area projection in the lower hemisphere using the software Stereonet of the poles of bedding measured directly in the field and on the virtual outcrop of the Andrín example shown in Fig. 8. Lines connect dip data measured in the field and on the virtual outcrop at the same position. b Bed thickness measured directly in the field and on the virtual outcrop of the Andrín example shown in Fig. 8. Adjacent bars correspond to measurements taken at the same localities. Only those measurements taken in the accessible parts of the outcrop are shown

Fig. 10 a Photointerpretation of a small-scale anticline over a field picture taken with a conventional photographic camera. b Ramsay graph for fold classification including data from the geological section derived from the photointerpretation depicted in $\mathbf{c}$ and from the geological profile derived from the 3D dataset depicted in $\mathbf{d}$. Compare the different paths obtained. $\mathbf{c}$ Isogon pattern of the anticline constructed on the geological section resulting from the photointerpretation illustrated in a. d Isogon pattern of the anticline constructed on a geological profile obtained from projecting the 3D geological interpretation of the point cloud using 3D Stereo VDT onto a plane striking N058 ${ }^{\circ} \mathrm{W}$. See location of the anticline within the Andrín outcrop in Fig. 8

Fig. 11 a Picture of the Cacabillo outcrop extracted from 2017 Google Earth images. The height difference between the bottom of the valley where the Sil River is located (lower part of the picture) and the highest peaks (to the northwest of Cacabillo) is approximately $500 \mathrm{~m}$. b Picture of the Cacabillo outcrop taken with a conventional photographic camera

Fig. 12 a Geological map and $\mathbf{b}$ geological section across the Cacabillo/Puerto de Somiedo anticline and adjacent structures showing the position of the Cacabillo outcrop. The cross section line is indicated in a. Simplified from Bastida et al. (1984)

Fig. 13 a Top, b inclined to the NW, and $\mathbf{c}$ horizontal to the N views of the Cacabillo-outcrop point cloud including an interpretation of key beds, main fold axial surfaces and faults carried out using the CAVE version of the software 3D Stereo VDT. See Figs. 4 and 12 for location of the outcrop

Fig. 14 Equal area projection in the lower hemisphere using the software Stereonet of measurements of axial surfaces of major folds, bedding measured in the northeast limb of the major folds and faults cutting and offsetting the limbs of the major folds in the Cacabillo example shown in Fig. 13. All the measurements plotted have been obtained from the virtual outcrop shown in Fig. 13

Fig. 15 Comparison of three geological sections across the Cacabillo outcrop. a Cross section constructed in the field (modified from Bastida et al. 1984). b Cross section constructed by plotting the 3D geological interpretation of the point cloud onto the plane $145 / 90$. c Cross section constructed by plotting the $3 \mathrm{D}$ geological interpretation of the point cloud onto the plane $145 / 80$

\section{Table captions}

Table 1 List of available software for 3D visualization and/or geological interpretation. 


\begin{tabular}{|c|c|c|c|c|c|c|}
\hline Software & Developer & Hardware & 3D Visualization & 3D trackers (interpretation) & Input tools & Reference \\
\hline $\begin{array}{l}\text { 3D Stereo } \\
\text { VDT }\end{array}$ & $\begin{array}{l}\text { Santiago Martín (Universidad de } \\
\text { Oviedo, Spain) }\end{array}$ & CAVE & Shutter glasses + CAVE & ( & $\begin{array}{l}\text { Wiimote }+ \\
\text { Nunchuk }\end{array}$ & This paper \\
\hline Lime & $\begin{array}{c}\text { Uni Research CIPR Bergen } \\
\text { (Norway) \& University of Aberdeen } \\
\text { (UK) }\end{array}$ & PC / Workstation & Shutter glasses / anaglyphs & No & $\begin{array}{l}\text { Keyboard }+ \\
\text { Mouse }\end{array}$ & http://virtualoutcrop.com/lime \\
\hline MOSIS & $\begin{array}{l}\text { L. Gonzaga Jr., M.R. Veronez, G.L. } \\
\text { Kannenberg, D. Nunes Alves, L. } \\
\text { Gomes Santana, J.L. de Fraga, L. } \\
\text { Campos Inocencio, L. Vieira de } \\
\text { Souza, F. Marson, F. Bordin, } \\
\text { F.M.W. Tognoli, K. Senger \& C.L. } \\
\text { Cazarin }\end{array}$ & $\begin{array}{l}\text { PC / Workstation } \\
\text { / Mobile }\end{array}$ & VR headset & Yes & $\begin{array}{l}\text { HTC Vive } \\
\text { controller }\end{array}$ & Gonzaga et al., 2018 \\
\hline MOVE & Midland Valley & PC / Workstation & Shutter glasses / anaglyphs & No & $\begin{array}{l}\text { Keyboard }+ \\
\text { Mouse }\end{array}$ & http://www.mve.com/software \\
\hline OpenPlot & $\begin{array}{l}\text { S. Tavani (Università degli Studi di } \\
\text { Napoli Federico II, Italy) }\end{array}$ & PC / Workstation & Shutter glasses / anaglyphs & No & $\begin{array}{l}\text { Keyboard + } \\
\text { Mouse }\end{array}$ & http://www.openplot.altervista.org \\
\hline $\begin{array}{l}\text { Outcrop } \\
\text { Explorer }\end{array}$ & $\begin{array}{l}\text { G. Marx Bellina, F.M. Wohnrath } \\
\text { Tognoli \& M.R. Veronez } \\
\text { (University of Vale do Rio dos } \\
\text { Sinos, Brazil) }\end{array}$ & PC / Workstation & No & No & $\begin{array}{l}\text { Keyboard }+ \\
\text { Mouse }\end{array}$ & Marx Bellina et al., 2016 \\
\hline VGRS & $\begin{array}{l}\text { D. Hodgetts (The University of } \\
\text { Manchester, UK) }\end{array}$ & PC / Workstation & VR headset & Yes & $\begin{array}{l}\text { Keyboard + } \\
\text { Mouse }\end{array}$ & http://www.vrgeoscience.com \\
\hline
\end{tabular}



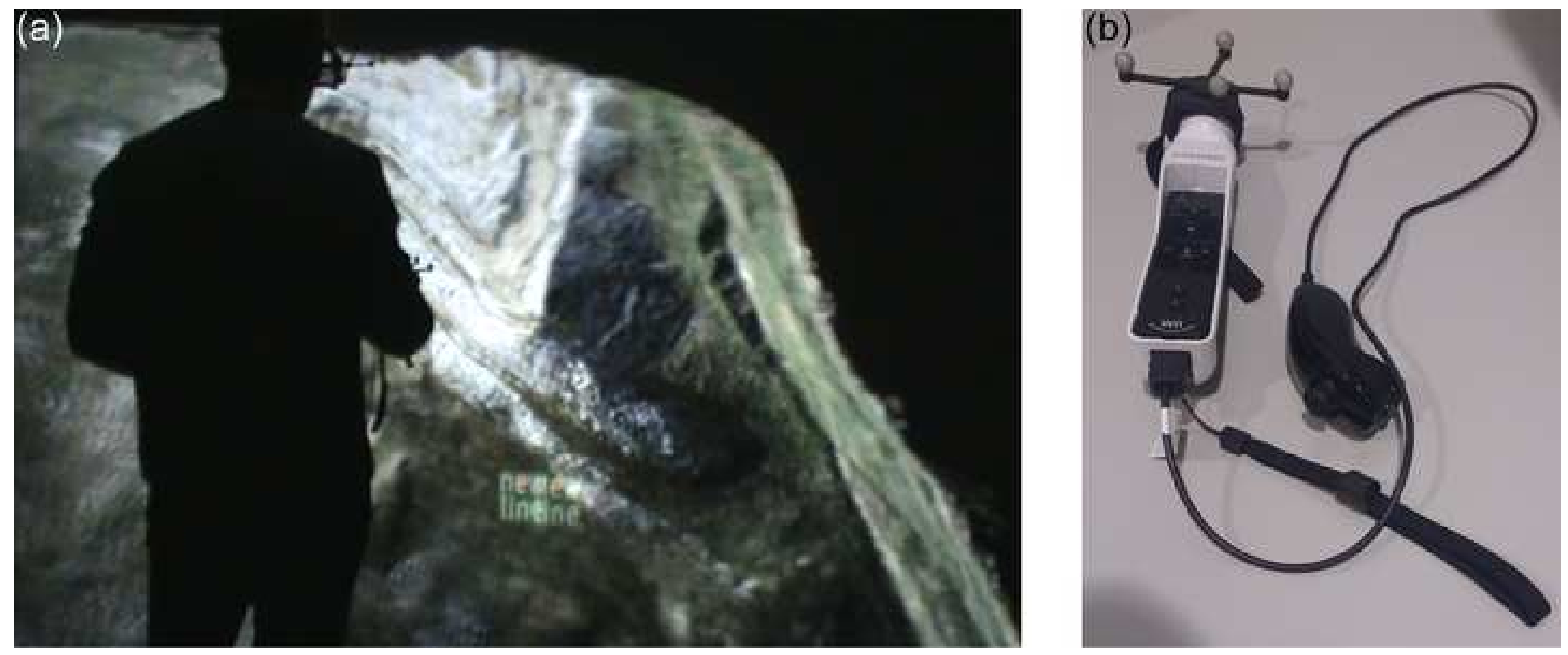


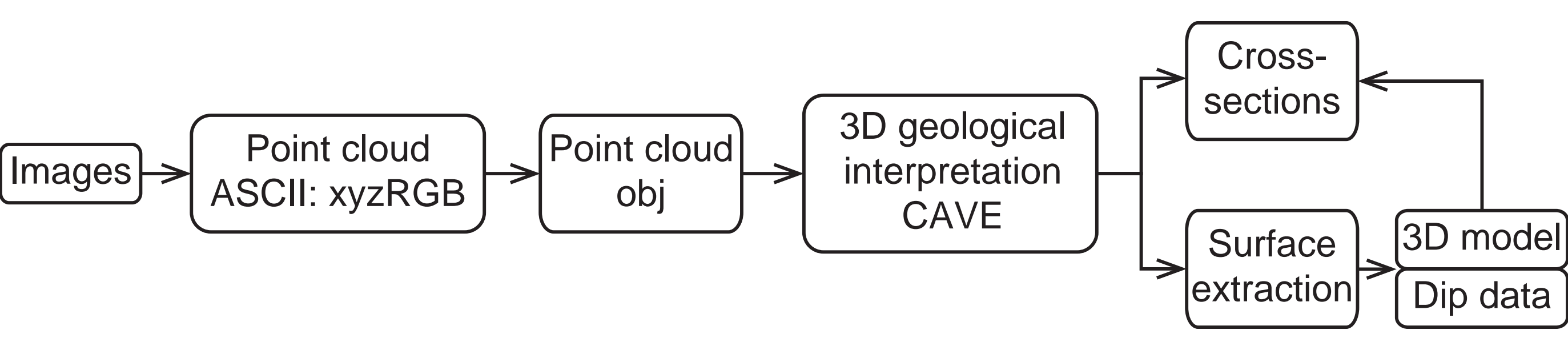


Fig 3

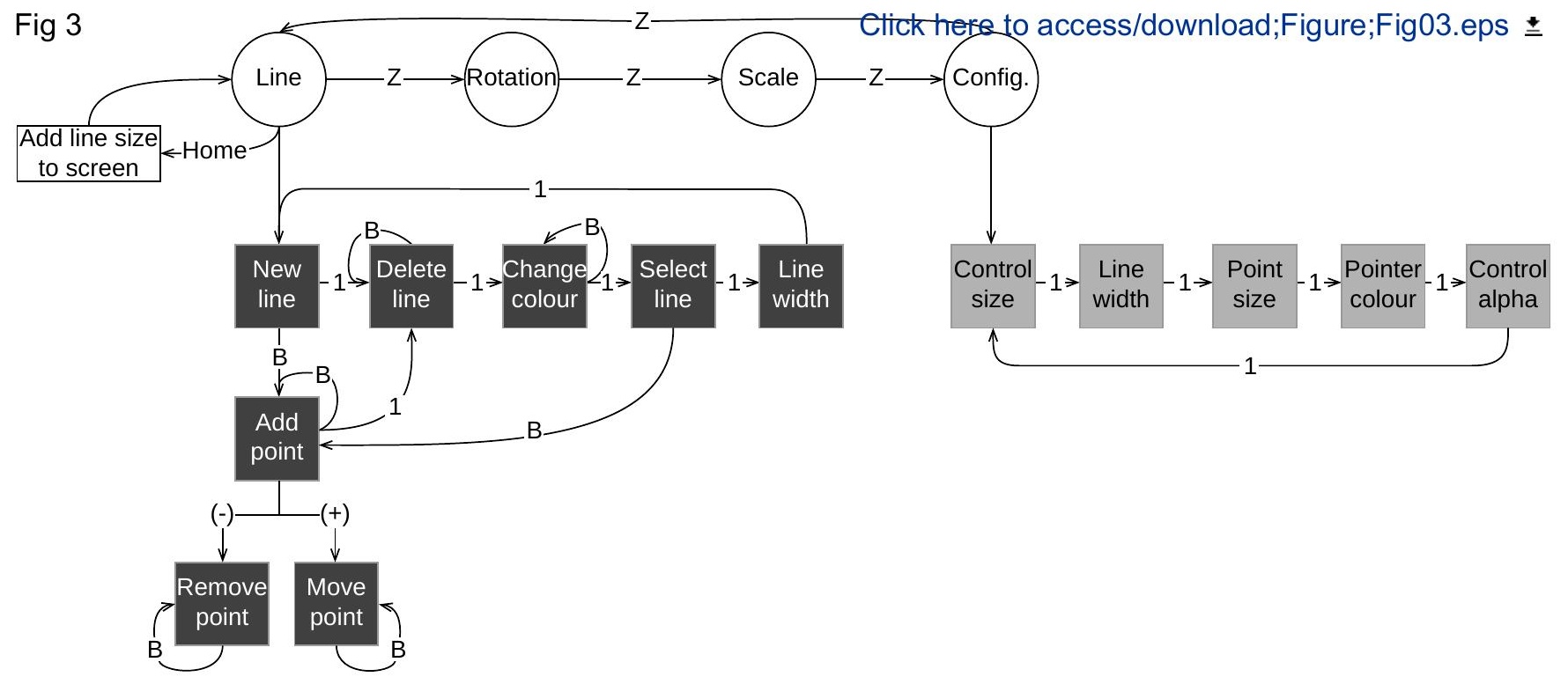




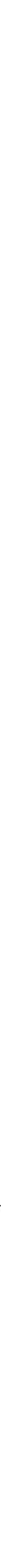




\section{SSE}

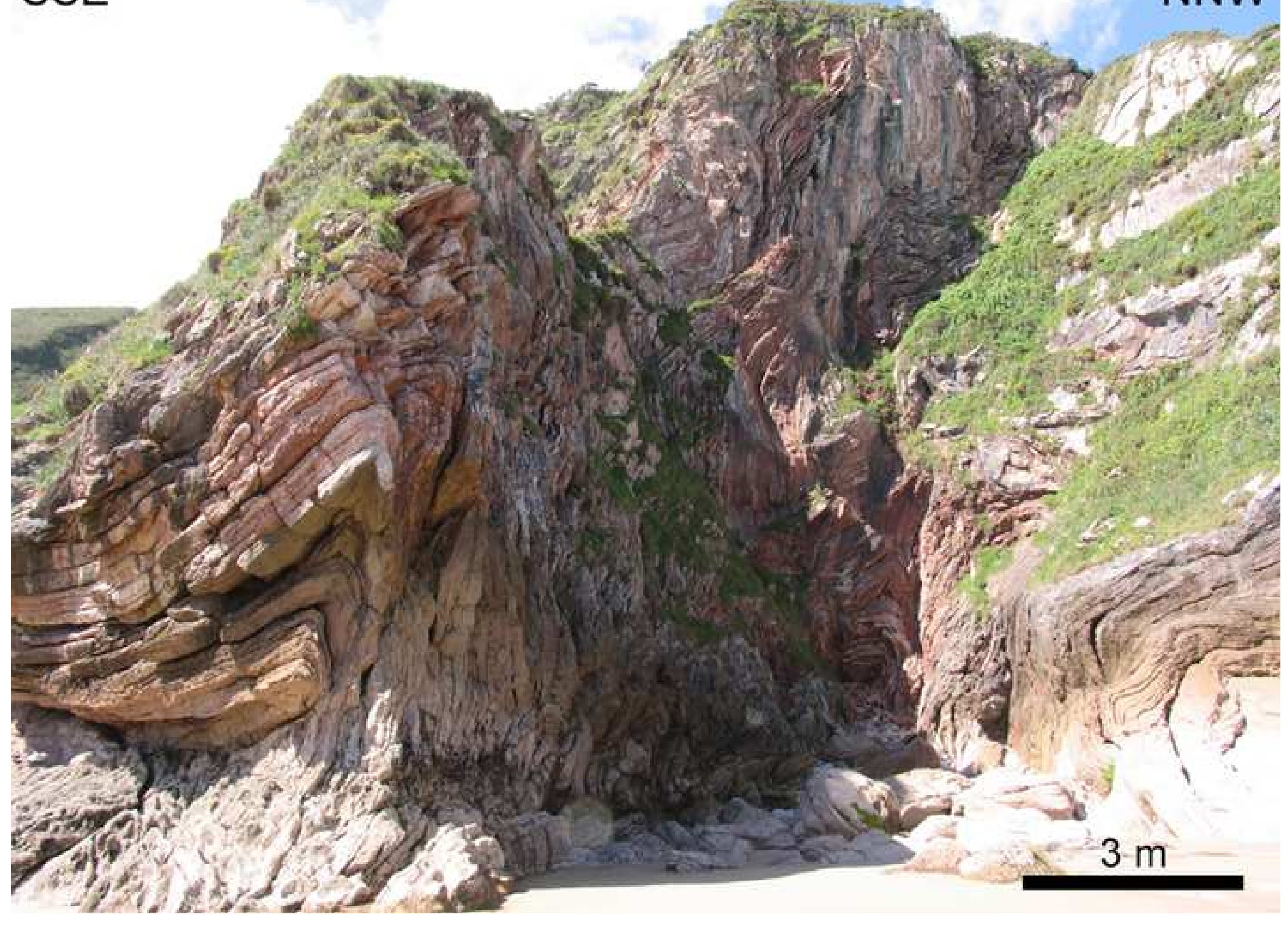

\section{NNW}




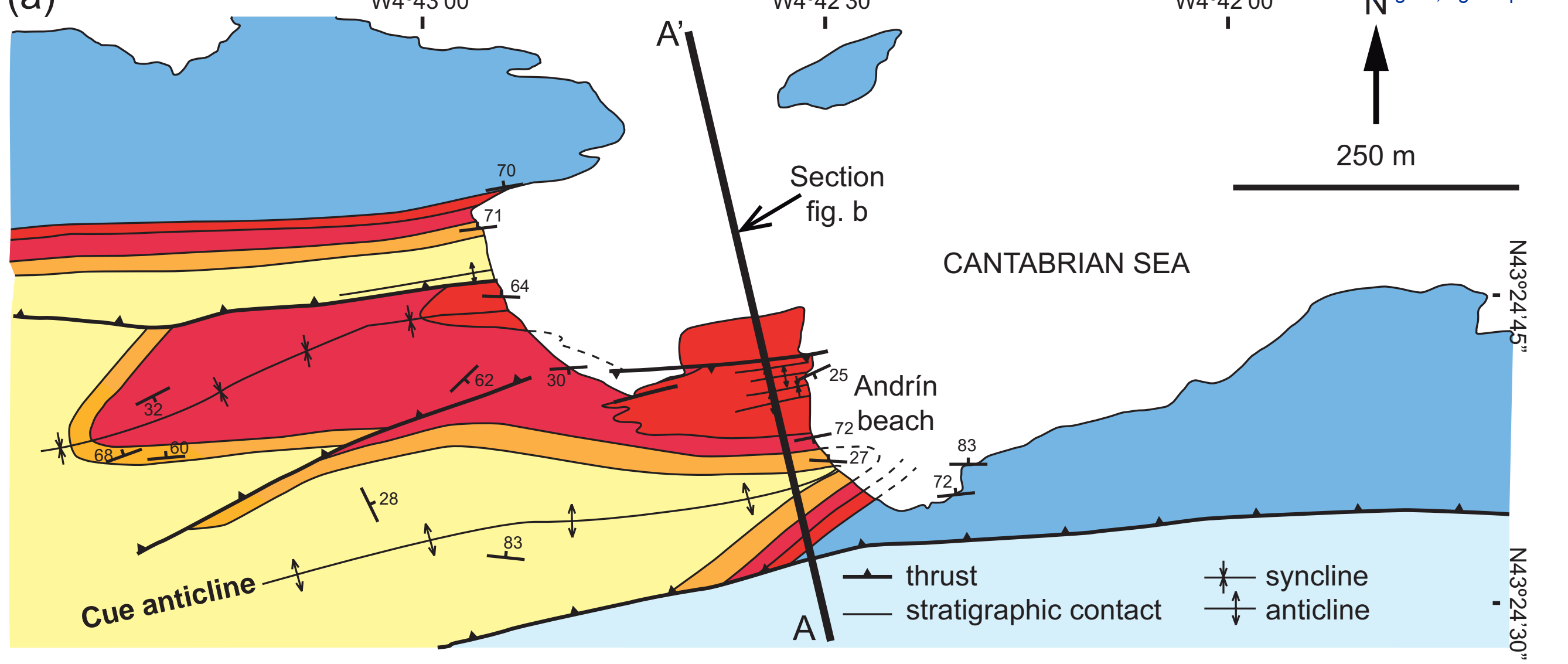

(b)

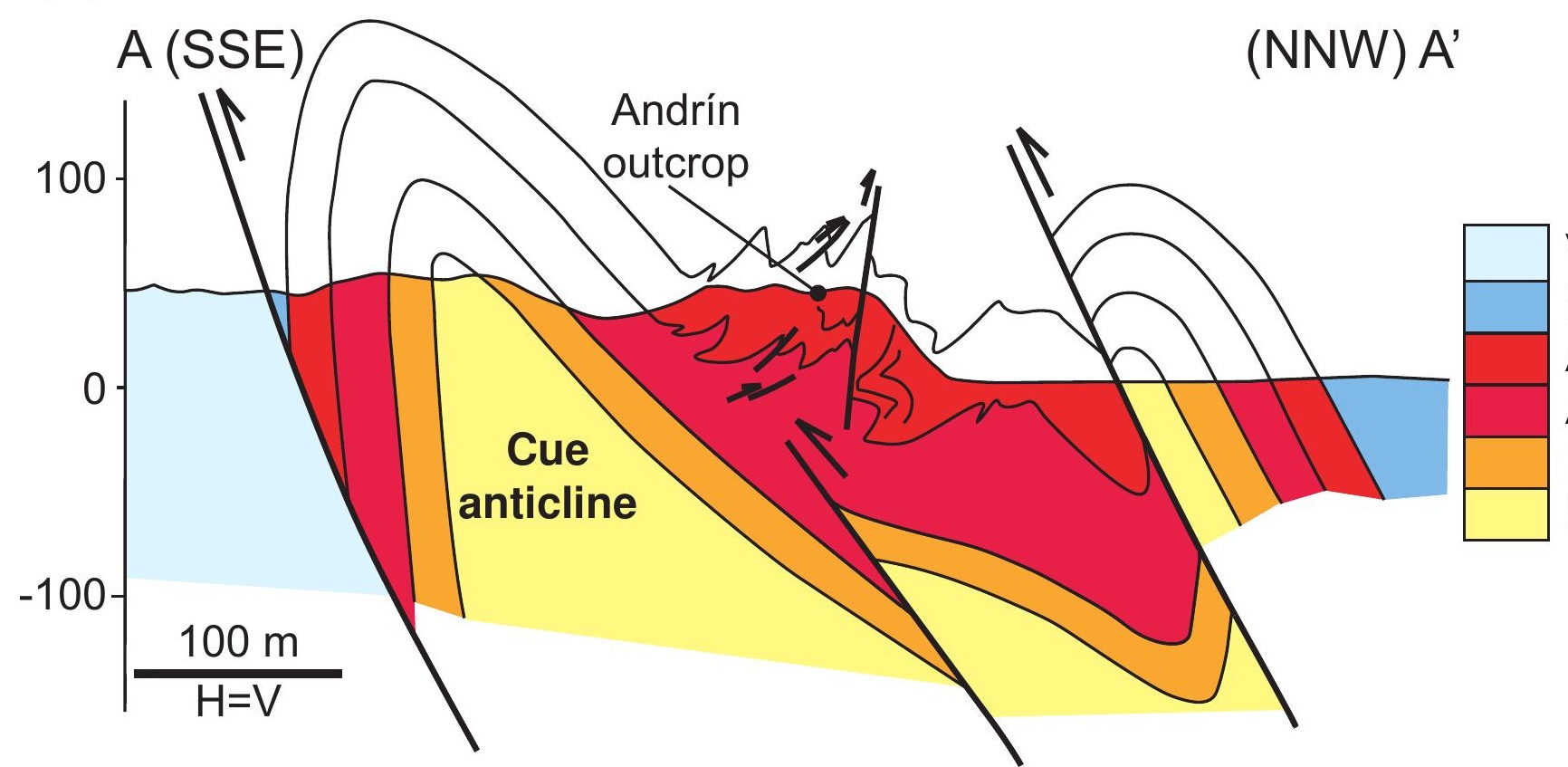

Valdeteja Fm. (Lower-Upper Carb.) Barcaliente Fm. (Lower Carb.) Alba Fm., griotte facies (Lower Carb.) Alba Fm., shales \& radiolarites (L. Carb.) Ermita Fm. (Upper Devonian) Barrios Fm. (M. Cambrian - L. Ordovician) 
(a)

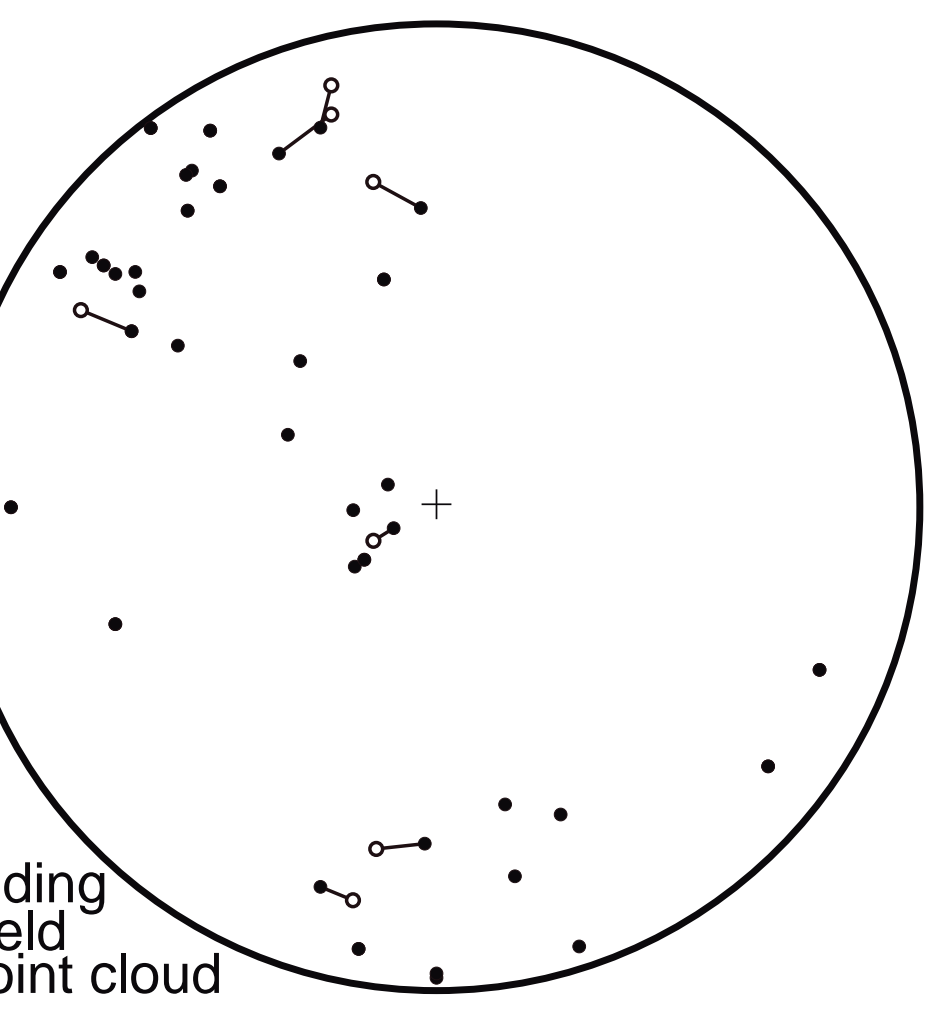

(b)

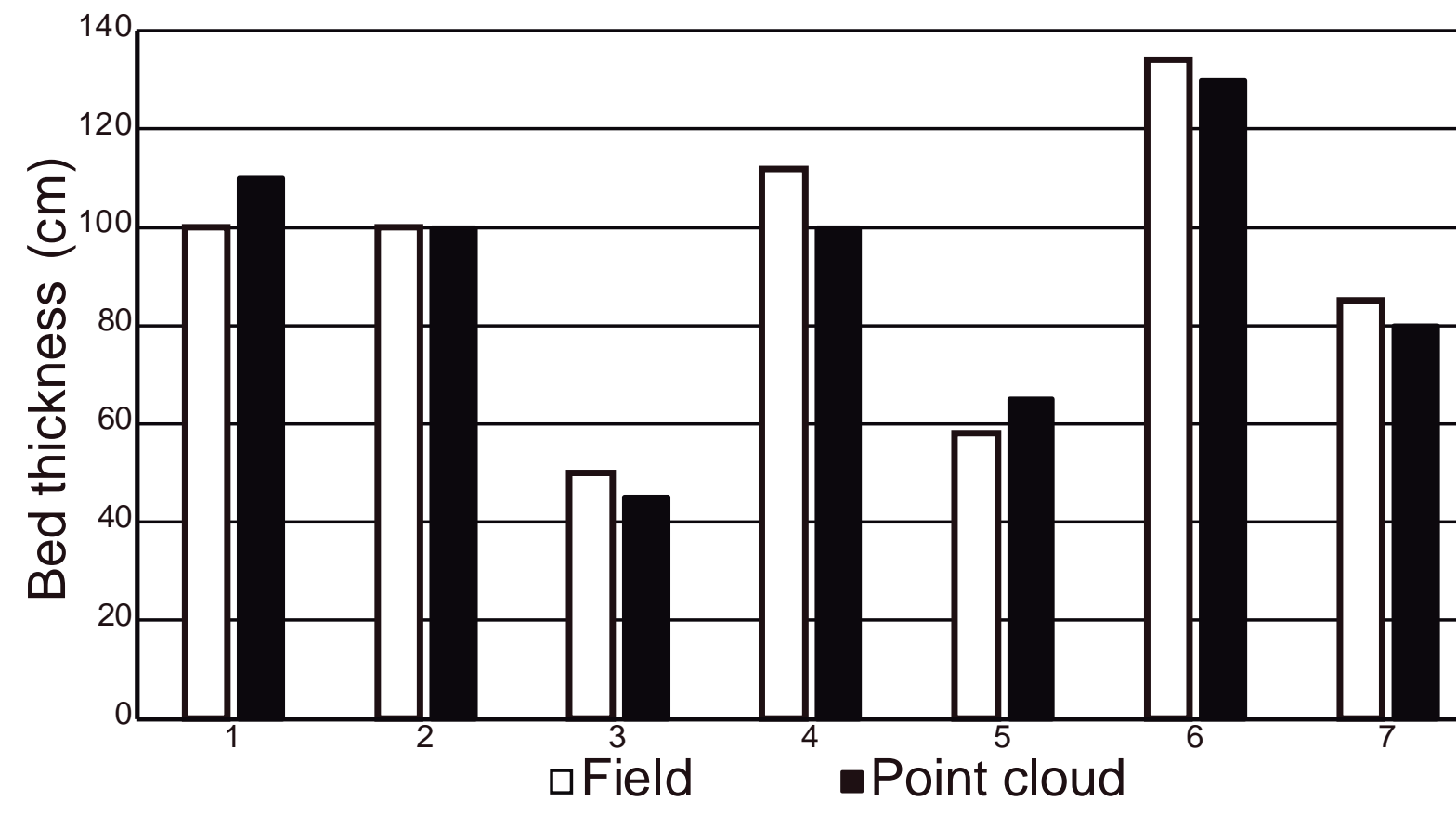


b)Click here to access/download;Figure;Fig10.eps $\underline{\underline{*}}$
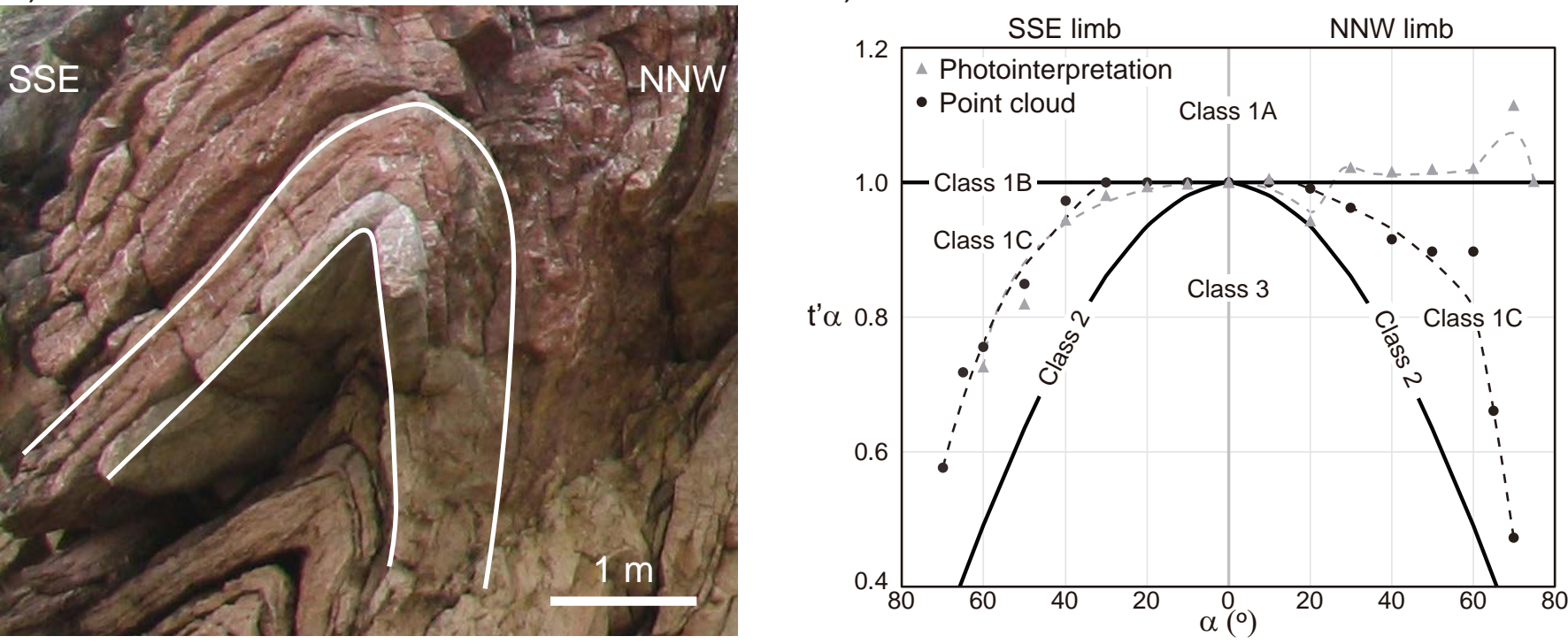

c)

\section{SSE}

d)

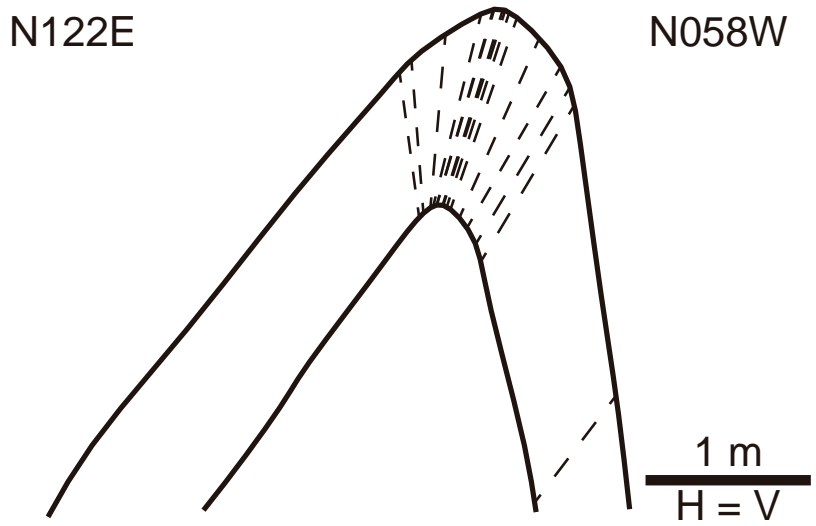



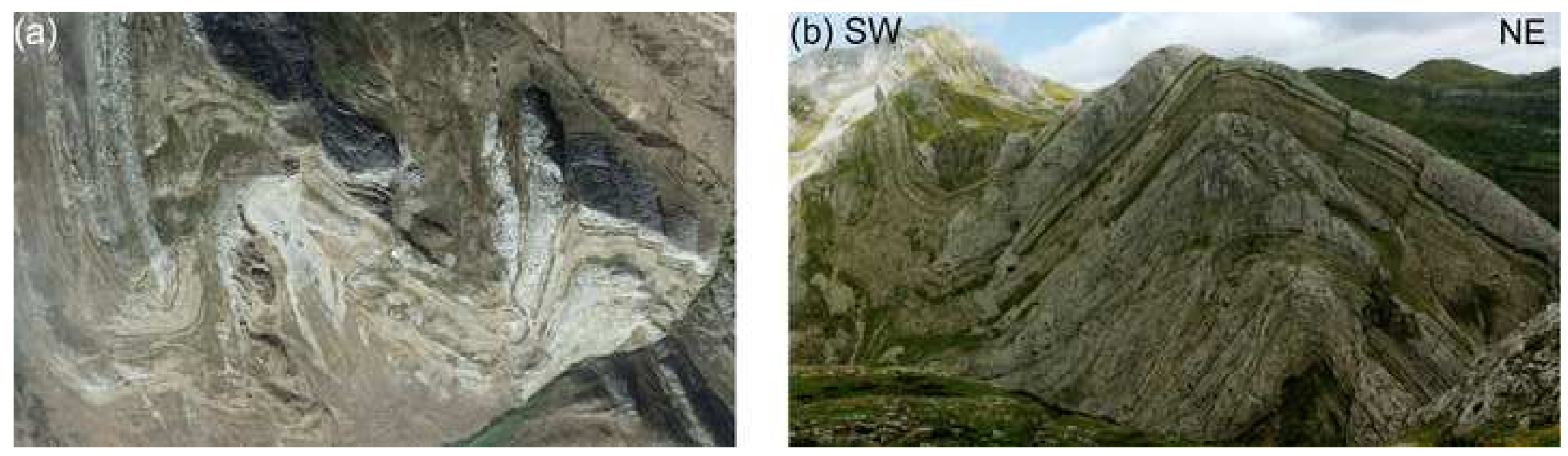


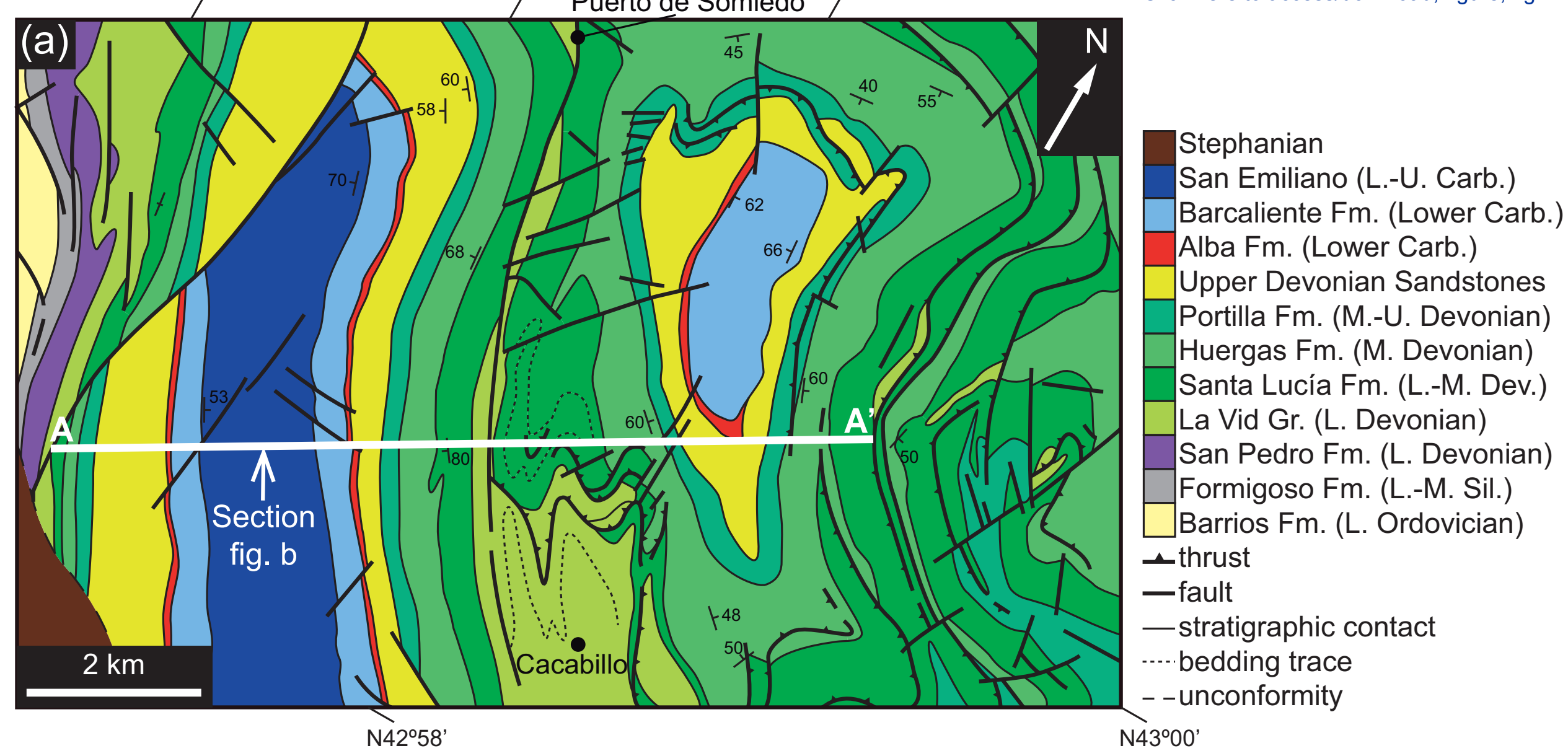

(b)

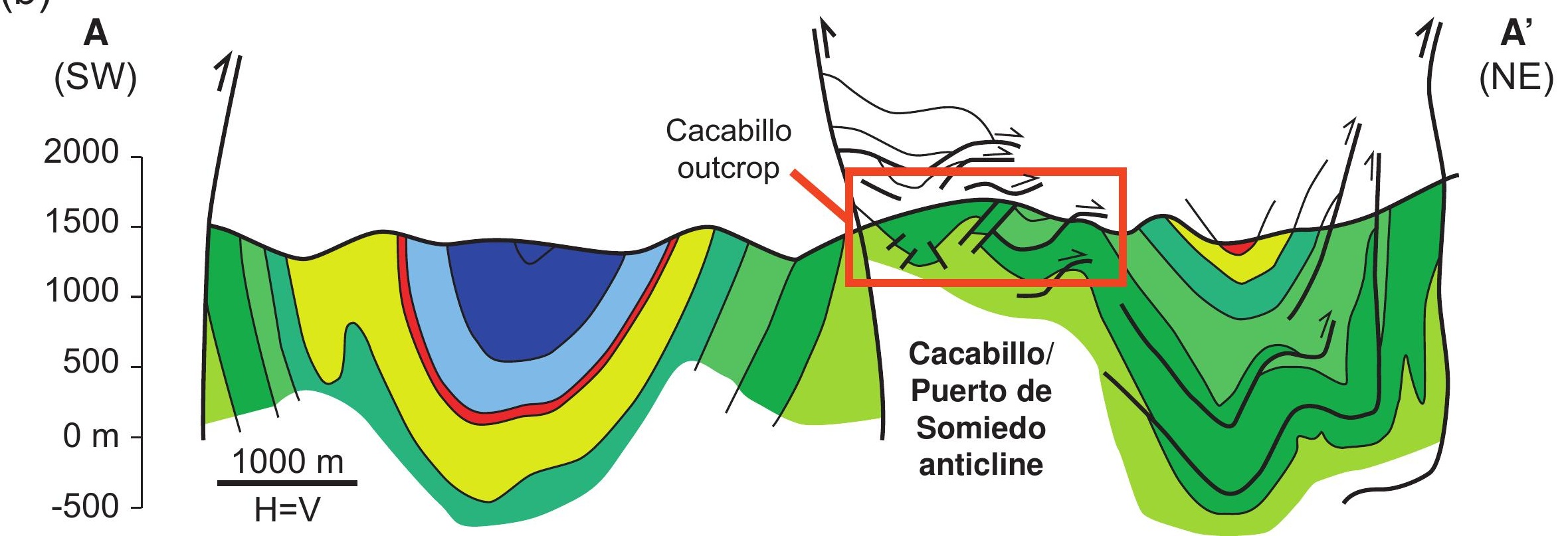

\section{7 ro}

N42 ${ }^{\circ} 58^{\prime}$
San Emiliano (L.-U. Carb.) Barcaliente Fm. (Lower Carb.)

Alba Fm. (Lower Carb.)

Upper Devonian Sandstones

Portilla Fm. (M.-U. Devonian)

Huergas Fm. (M. Devonian)

Santa Lucía Fm. (L.-M. Dev.)

La Vid Gr. (L. Devonian)

Devonian)

Formigoso Fm. (L.-M. Sil.)

Barrios Fm. (L. Ordovician)

-.... bedding trace

$\mathrm{N} 43^{\circ} 00^{\prime}$ 


\section{Santa}

Lucía Fm.

La Vid Gr. $\leftrightarrow$

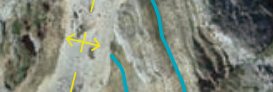

$\underline{\underline{ }}$

ig13.eps

bedding fault thrust

- $\hat{\downarrow}-\frac{\text { anticline }}{\text { axial plane }}$

* syncline axial plane $250 \mathrm{~m}$ $\mathrm{H}=\mathrm{V}$

(b)

(c)
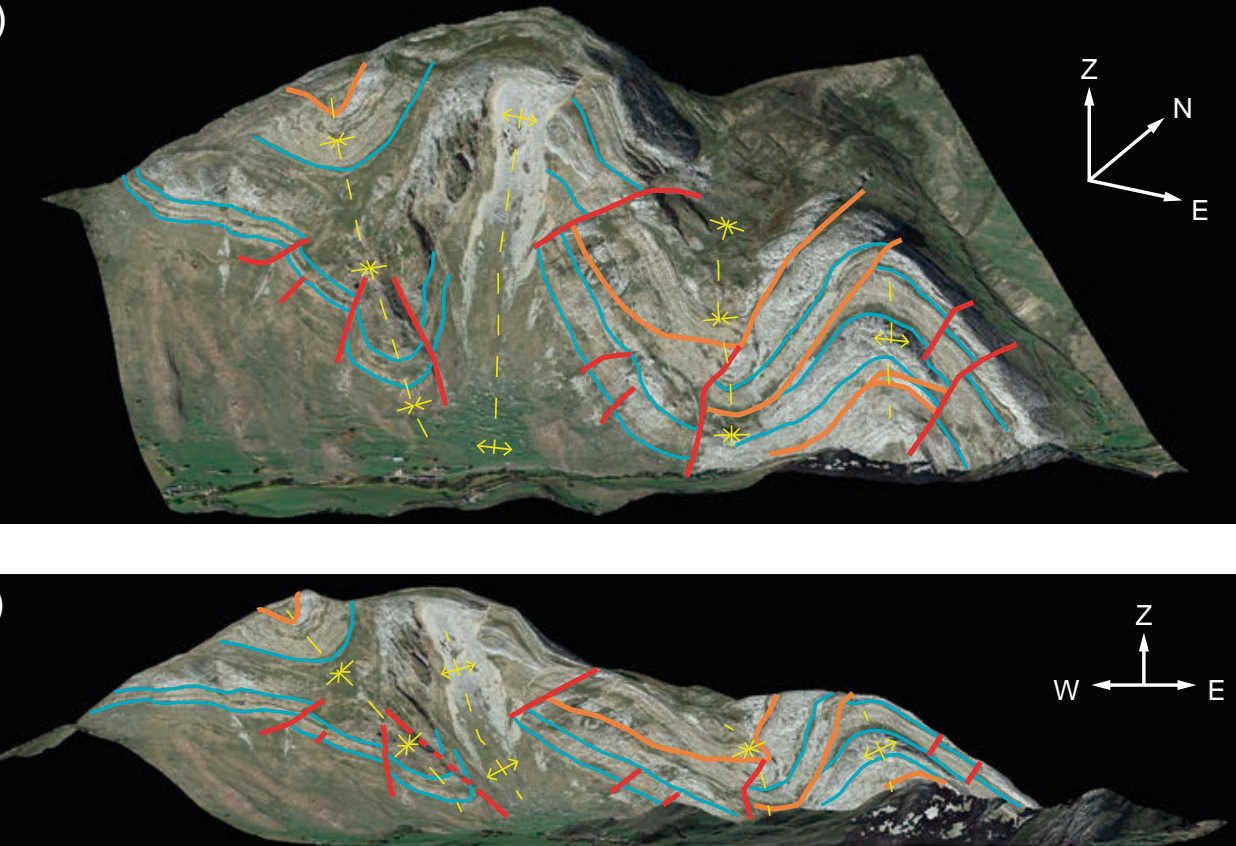


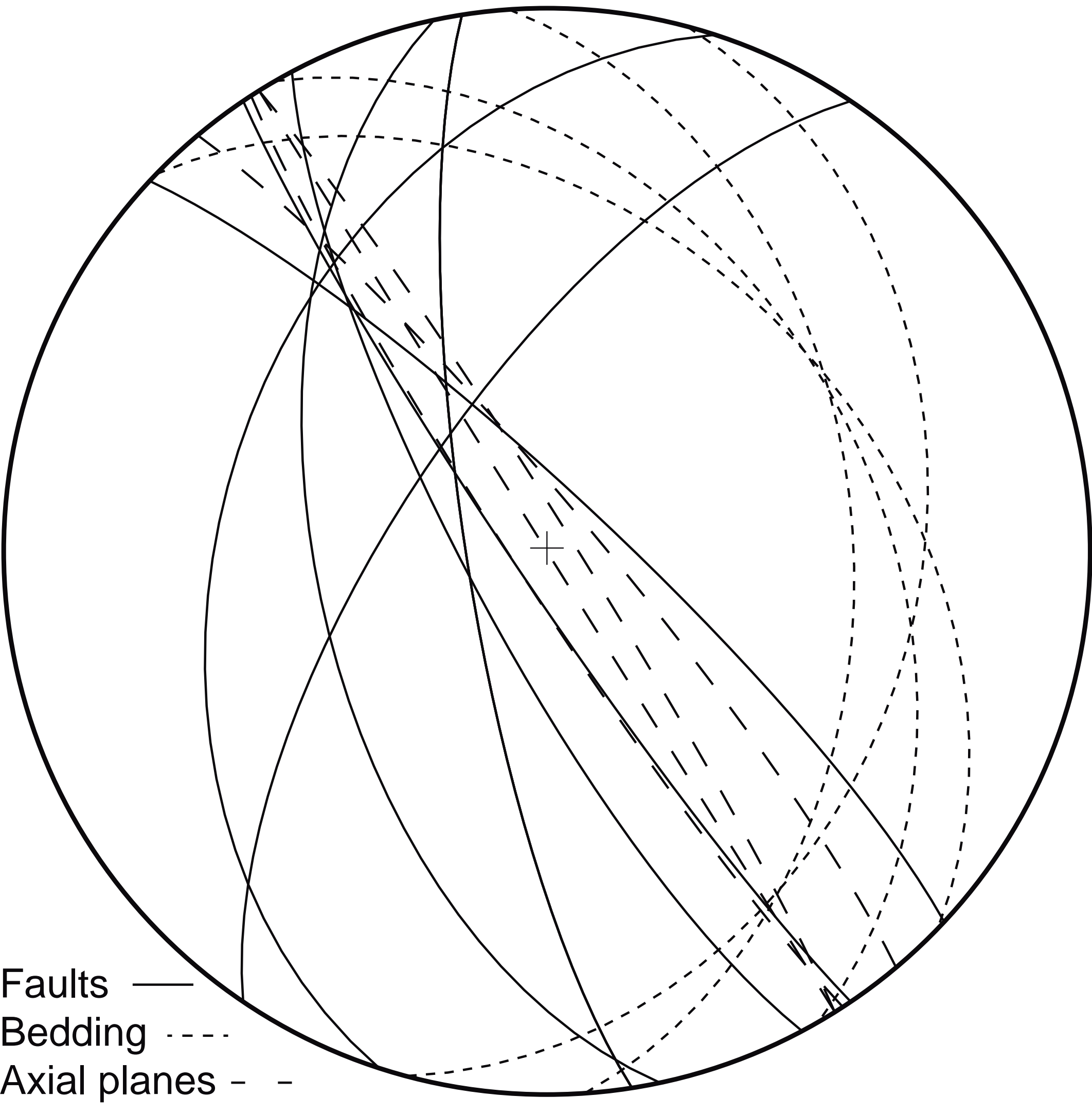




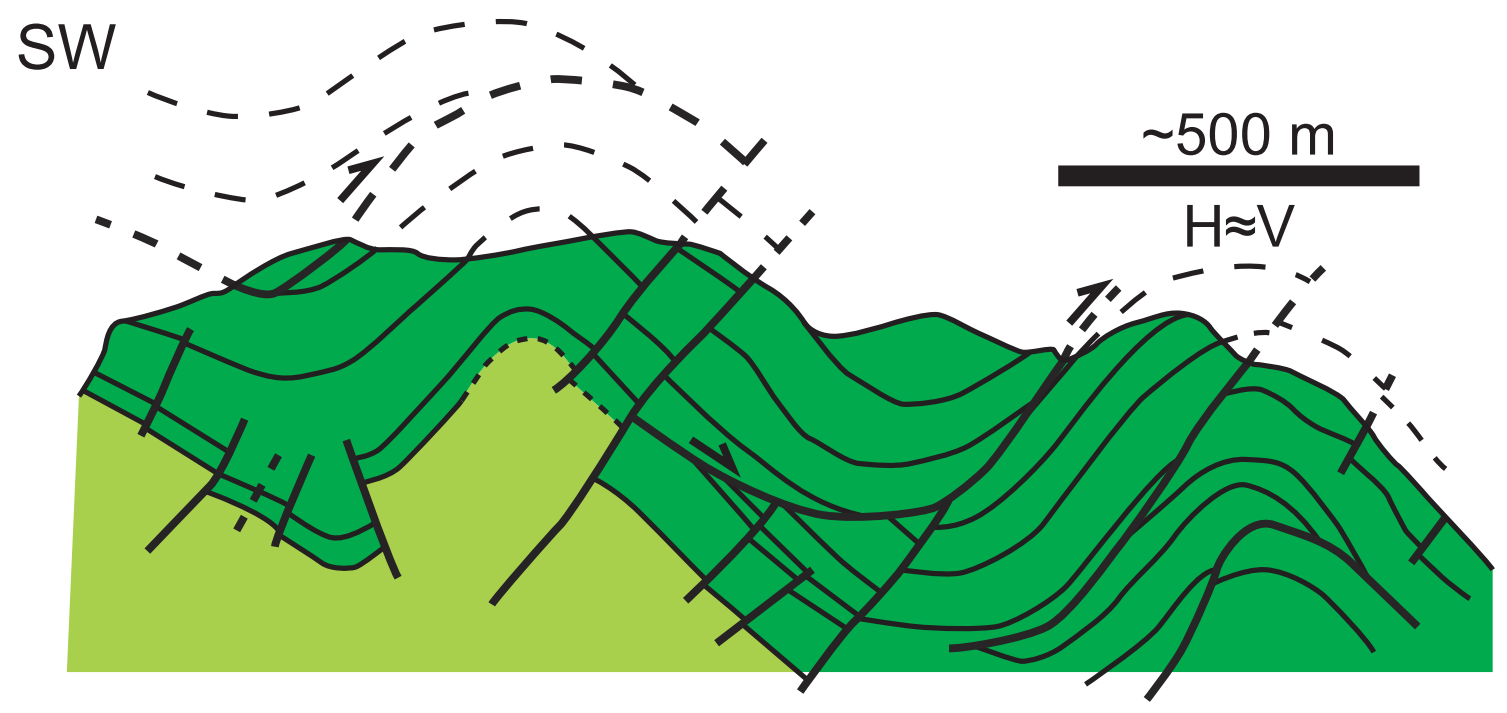

(b)

(Section plane: 145/90 - vertical section)

N125W

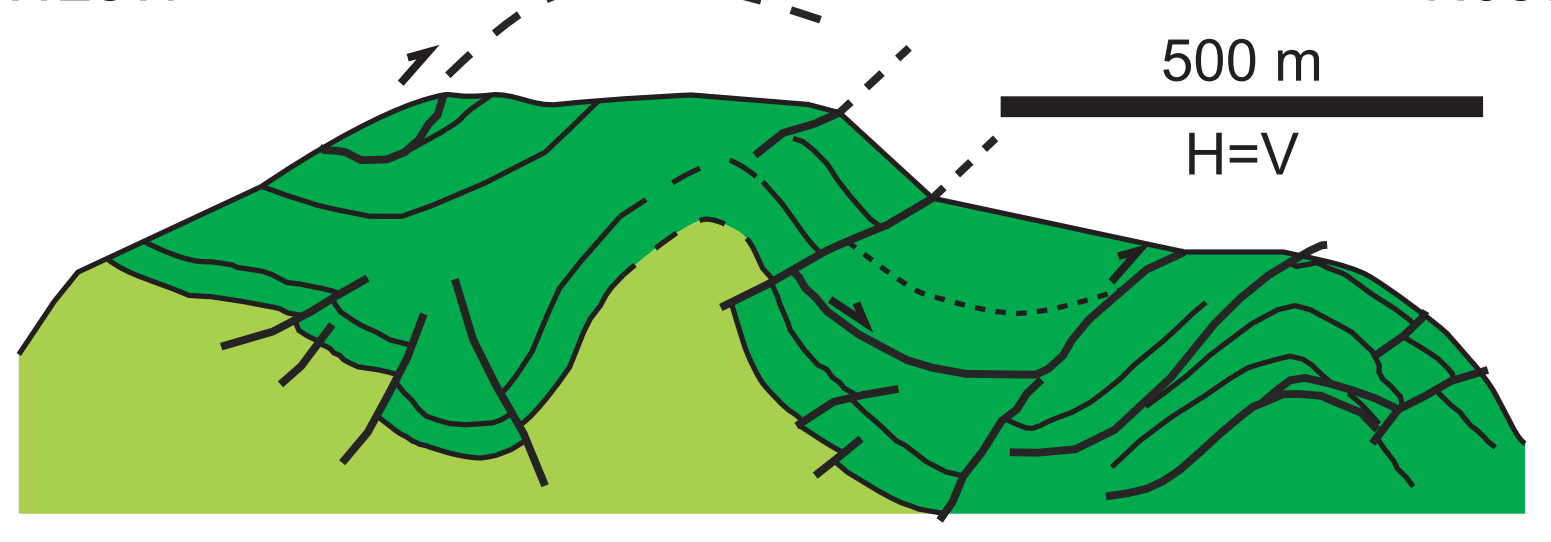

(c)

(Section plane: 145/80 - inclined section)

N125W

N055E

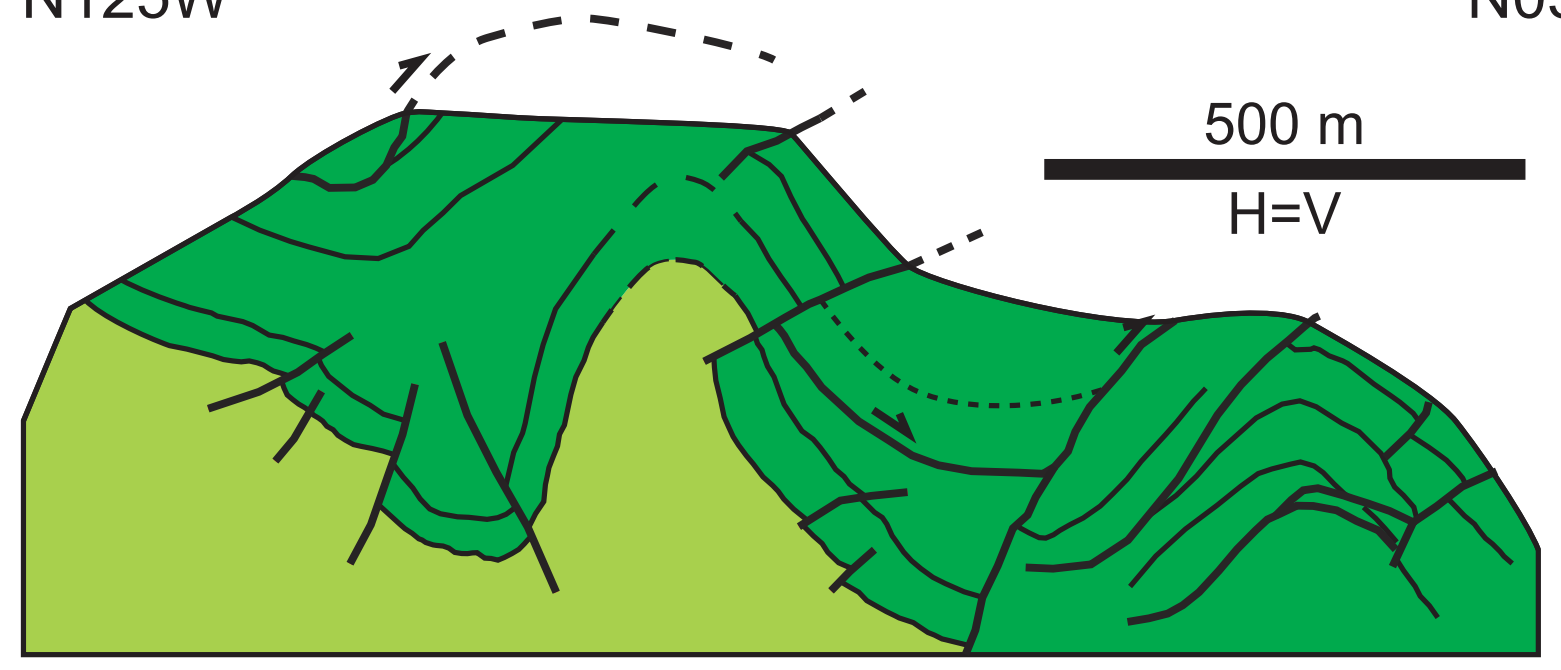

Santa Lucía Fm. (Lower-Middle Devonian)

La Vid Gr. (Lower Devonian) 
Dear Editor,

We have modified both the text and figures according to all the comments (general and minor comments) suggested by reviewer 1 and reviewer 2 . Only one suggestion has not been introduced: we have not been able to measure more dips and strikes of bedding in the 3D model of the Cacabillo outcrop in order to estimate the fold axis.

Yours sincerely,

Santiago Martín, Hodei Uzkeda, Josep Poblet and Mayte Bulnes 